\title{
Heat, salt, and volume transports in the eastern Eurasian Basin of the Arctic Ocean from 2 years of mooring observations
}

\author{
Andrey V. Pnyushkov ${ }^{1}$, Igor V. Polyakov ${ }^{2}$, Robert Rember ${ }^{1}$, Vladimir V. Ivanov ${ }^{4,6}$, Matthew B. Alkire ${ }^{3}$, \\ Igor M. Ashik ${ }^{4}$, Till M. Baumann ${ }^{1}$, Genrikh V. Alekseev ${ }^{4}$, and Arild Sundfjord ${ }^{5}$ \\ ${ }^{1}$ International Arctic Research Center, University of Alaska Fairbanks, Fairbanks, AK, USA \\ ${ }^{2}$ International Arctic Research Center and College of Natural Science and Mathematics, \\ University of Alaska Fairbanks, Fairbanks, AK, USA \\ ${ }^{3}$ Applied Physics Laboratory, University of Washington, Seattle, WA, USA \\ ${ }^{4}$ Arctic and Antarctic Research Institute, St. Petersburg, Russia \\ ${ }^{5}$ Norwegian Polar Institute, Fram Centre, Troms $\varnothing$, Norway \\ ${ }^{6}$ Moscow State University, Geography department, Moscow, Russia
}

Correspondence: Andrey V. Pnyushkov (avpnyushkov@alaska.edu)

Received: 20 March 2018 - Discussion started: 23 April 2018

Revised: 2 October 2018 - Accepted: 14 October 2018 - Published: 2 November 2018

\begin{abstract}
This study discusses along-slope volume, heat, and salt transports derived from observations collected in 2013-2015 using a cross-slope array of six moorings ranging from 250 to $3900 \mathrm{~m}$ in the eastern Eurasian Basin (EB) of the Arctic Ocean. These observations demonstrate that in the upper $780 \mathrm{~m}$ layer, the along-slope boundary current advected, on average, $5.1 \pm 0.1 \mathrm{~Sv}$ of water, predominantly in the eastward (shallow-to-right) direction. Monthly net volume transports across the Laptev Sea slope vary widely, from $\sim 0.3 \pm 0.8$ in April 2014 to $\sim 9.9 \pm 0.8 \mathrm{~Sv}$ in June $2014 ; 3.1 \pm 0.1 \mathrm{~Sv}$ (or $60 \%$ ) of the net transport was associated with warm and salty intermediate-depth Atlantic Water (AW). Calculated heat transport for 2013-2015 (relative to $-1.8^{\circ} \mathrm{C}$ ) was $46.0 \pm 1.7 \mathrm{TW}$, and net salt transport (relative to zero salinity) was $172 \pm 6 \mathrm{Mkg} \mathrm{s}^{-1}$. Estimates for AW heat and salt transports were $32.7 \pm 1.3 \mathrm{TW}(71 \%$ of net heat transport) and $112 \pm 4 \mathrm{Mkg} \mathrm{s}^{-1}$ (65\% of net salt transport). The variability of currents explains $\sim 90 \%$ of the variability in the heat and salt transports. The remaining $\sim 10 \%$ is controlled by temperature and salinity anomalies together with the temporal variability of the AW layer thickness. The annual mean volume transports decreased by $25 \%$ from 5.8 $\pm 0.2 \mathrm{~Sv}$ in 2013-2014 to 4.4 $\pm 0.2 \mathrm{~Sv}$ in 2014-2015, suggesting that changes in the transports at interannual and longer timescales in the eastern EB may be significant.
\end{abstract}

\section{Introduction}

Propagating along the deep basin margins of the Arctic Ocean, the Arctic Circumpolar Boundary Current (ACBC; Aksenov et al., 2011) carries substantial amounts of Atlanticorigin heat and salt (Aagaard and Greisman, 1975; Schauer et al., 2008). The role of Atlantic Water (AW) heat advected by the ACBC in recent sea ice loss and thermohaline changes in the Eurasian Basin (EB) of the Arctic Ocean is still under debate (e.g., Carmack et al., 2015, for discussion). However, the AW heat may be important for the state of sea ice in regions where heat can be released to the bottom of sea ice by winter ventilation (Onarheim et al., 2014; Ivanov et al., 2016; Polyakov et al., 2017). Thus, quantifying ACBC transports is essential for understanding the current and future state of the Arctic Ocean and sea ice.

Warm and salty intermediate-depth $(\sim 150-800 \mathrm{~m})$ AW penetrates into the Arctic Ocean through two major gateways. The Fram Strait branch of AW enters the EB with the West Spitsbergen Current (WSC) through the eastern part of Fram Strait - the passage between Spitsbergen and the Greenland shelf (Fig. 1). The second Barents Sea AW branch enters the Arctic Ocean through the Barents Sea Opening and then flows into the EB through the St. Anna Trough. North of the Kara Sea, these branches merge laterally and propagate further along the EB slope in the shallow-to-right direction as two distinct flows, forming a confluence area along the 


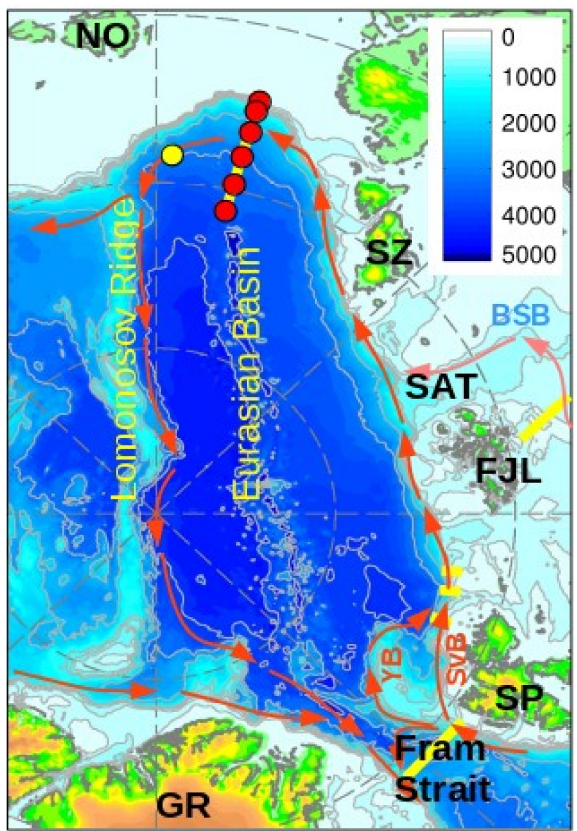

Figure 1. Map showing the location of moorings (red circles) over the continental slope of the Laptev Sea in the Eurasian Basin of the Arctic Ocean in 2013-2015. Greenland (GR), Spitsbergen (SP), Franz Josef Land (FJL), St. Anna Trough (SAT), Severnaya Zemlya (SZ), and Novosibirskiye Islands (NO) are indicated. YB, SvB, and BSB indicate Yermak, Svalbard, and Barents Sea Atlantic Water (AW) branches, respectively. Red arrows show a schematic pattern of AW circulation in the Eurasian Basin. Bottom depth in meters is shown by color. Oceanographic sections and moorings mentioned in the paper are indicated with yellow lines and circles.

shelf slope between the St. Anna Trough and the Lomonosov Ridge with a distinctive thermohaline front between these two streams (Schauer et al., 2002; Baumann et al., 2018). After the confluence, the Barents Sea AW branch flows eastward over the upper EB slope, while the Fram Strait branch occupies a broad segment of the lower slope.

Despite the important role the ACBC plays for the heat and salt balance of the EB, trustworthy observational estimates for heat, salt, and volume transports are rare. For the eastern EB, in particular for the central Laptev Sea slope, to our knowledge such estimates do not yet exist. However, observations made during the period of 2013-2015 by an array of six moorings crossing the continental slope of the Laptev Sea along the $125^{\circ}$ E meridian (Fig. 2) were used in this study to provide the first estimates of volume, heat, and salt transports carried by the ACBC in the eastern EB (Fig. 1). These mooring records of water temperature, salinity, and current velocities were collected under the auspice of the Nansen and Amundsen Basins Observational System (NABOS) program. We describe here the temporal variability of these transports at scales resolved by the available mooring records. This study is focused on transports in the upper $780 \mathrm{~m}$ layer (limited by the available observations), with a particular focus on the AW, which is the major constituent of the ACBC transports at the Laptev Sea slope.

\section{Background information}

\subsection{Water mass structure in the eastern EB and Laptev Sea}

Climatological temperature and salinity profiles enable insight regarding the vertical structure of the water column at the Laptev Sea slope. Here we use the Polar Hydrographic Climatology (PHC) dataset compiled for the 1970s-1990s (Steele at al., 2001). According to the PHC temperatures and salinities averaged over the area $77-79^{\circ} \mathrm{N}$ and $125-126^{\circ} \mathrm{E}$, the upper $\sim 30 \mathrm{~m}$ layer of the water column in summer and $\sim 50 \mathrm{~m}$ in winter is occupied by relatively fresh $(S<34)$ and well-mixed waters forming the surface mixed layer (SML; Fig. 2, bottom panels). The thickness of the SML and its temperature and salinity vary across the slope and experience substantial seasonal changes due to interaction with the polar atmosphere, entrainment of deep water, and ice formation and melting (e.g., Baumann et al., 2018). In the cold halocline layer (CHL; 30-100 m depth range), which underlies the SML, salinity increases with depth, while temperature is still close to the freezing point (Fig. 2; Aagaard et al., 1981; Rudels et al., 1996). A strong density stratification in this layer due to salinity gradients suppresses the vertical exchange of heat and salt with the relatively warm $\left(T>0{ }^{\circ} \mathrm{C}\right)$ AW below (Aagaard and Greisman, 1975; Aagaard et al., 1981; Rudels et al., 1996).

Between the CHL and the AW temperature core, both temperature and salinity increase with depth, forming the low halocline layer (e.g., Alkire et al., 2017). The AW at the central Laptev Sea slope occupies the intermediate layer (typically below $150 \mathrm{~m}$; Dmitrenko et al., 2006). According to the PHC dataset, the Fram Strait branch of the AW spans the layer between $\sim 180$ and $\sim 750 \mathrm{~m}$ (determined by the position of $0^{\circ} \mathrm{C}$ isotherm), but for some years, the lower AW boundary determined using measured conductivitytemperature-depth (CTD) profiles can be found significantly deeper at $\sim 1000-1200 \mathrm{~m}$ (see, for example, Fig. 7 in Pnyushkov et al., 2015).

Climatological temperatures and salinities suggest that, at the Laptev Sea slope, the Barents Sea branch of AW underlies the Fram Strait branch (Fig. 2). Before reaching the Laptev Sea slope, the Barents Sea branch of the AW experiences strong thermal transformation caused by interaction with the cold atmosphere, local waters, and sea ice. At the exit from the Barents Sea, this water has predominantly negative temperatures, $27.8<\sigma<28.0 \mathrm{~kg} \mathrm{~m}^{-3}$ density range (e.g., Pfirman et al., 1994; Schauer et al., 1997, 
(a)
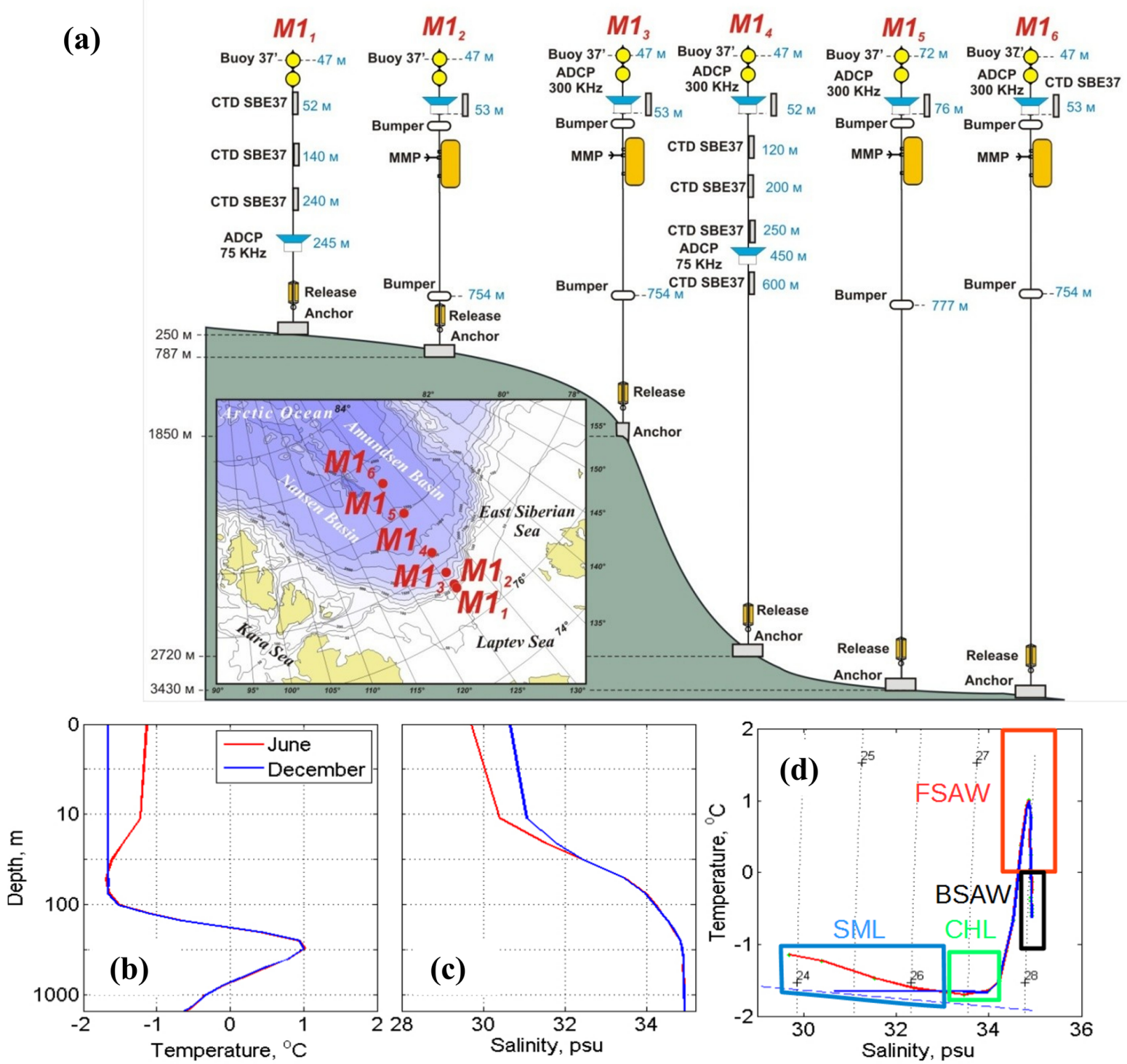

Figure 2. (a) Schematics and locations (insert) of six moorings deployed as a cross-slope array in the eastern Eurasian Basin along $125^{\circ} \mathrm{E}$ in 2013-2015. Note that the distances between the moorings shown in these schematics do not reflect real distances (as shown in insert). $(\mathbf{b}, \mathbf{c})$ Climatological potential temperature $(\theta)$ and salinity $(S)$ profiles and (d) $\theta-S$ diagram for the central Laptev Sea slope area $\left(77-79^{\circ} \mathrm{N}\right.$; $125-126^{\circ} \mathrm{E}$ ). In panel (d), gray dotted lines show isopycnals, and the blue dashed line shows freezing temperature. Vertical distribution of the climatological potential density resembles salinity distribution shown in panel (c). Color rectangles emphasize different water masses occupying the Laptev Sea slope. SML, CHL, FSAW, and BSAW in the $T-S$ plot indicate the surface mixed layer, the cold halocline layer, the Fram Strait Atlantic Water, and the Barents Sea Atlantic Water, respectively.

2002; Lien and Trofimov, 2013), and propagates along the EB slope at depths below $700-800 \mathrm{~m}$.

\subsection{AW transports}

ACBC transport over the Laptev Sea slope is influenced by inflows from both the Fram Strait and the Barents Sea AW branches. Providing a large influx of water and potential vorticity from the Nordic and the Barents seas, these inflows change the large-scale pattern of sea level in the EB (e.g.,
Karcher et al., 2007; Aksenov et al., 2011) and thus serve as remote forcing for transport changes to the Laptev Sea region. The long-term monitoring of AW inflow through Fram Strait was established in 1997 (Fahrbach et al., 2001; Schauer et al., 2004). Following Beszczynska-Möller et al. (2012), this inflow consists of several types of AW: the warm AW (water warmer than $2{ }^{\circ} \mathrm{C}$ ), which propagates along the slope in the upper $400 \mathrm{~m}$ layer as a continuation of the Norwegian Atlantic Current, and the modified returning AW. Mooring- 
Table 1. Estimates of volume transport in the Eurasian Basin of the Arctic Ocean.

\begin{tabular}{|c|c|c|c|c|}
\hline Location & Period & Water properties & $\begin{array}{l}\text { AW volume } \\
\text { transport, Sv }\end{array}$ & Source \\
\hline Fram Strait & 1997-2019 & $T>2{ }^{\circ} \mathrm{C}$ & $3.0 \pm 0.2$ & Beszczynska-Möller et al. (2012) \\
\hline $\begin{array}{l}\text { North of Spitsbergen } \\
\left(\text { near } 30^{\circ} \mathrm{E}\right)\end{array}$ & Sep 2012 & $\begin{array}{l}27.7<\sigma<27.97 \\
\mathrm{~kg} \mathrm{~m}^{-3} \text { and } T>2{ }^{\circ} \mathrm{C}\end{array}$ & $1.6 \pm 0.3$ & Våge et al. (2016) \\
\hline $\begin{array}{l}\text { North of Spitsbergen } \\
\text { (between } 21 \text { and } 33^{\circ} \mathrm{E} \text { ) }\end{array}$ & Sep 2013 & $\begin{array}{l}27.7<\sigma<27.97 \\
\mathrm{~kg} \mathrm{~m}^{-3} \text { and } S>34.9\end{array}$ & $2.31 \pm 0.29$ & Pérez-Hernández et al. (2017) \\
\hline $\begin{array}{l}\text { The strait between } \\
\text { Franz Josef Land } \\
\text { and Novaya Zemlya }\end{array}$ & $\begin{array}{l}\text { Sep 1991- } \\
\text { Sep } 1992\end{array}$ & Barents Sea AW & $\sim 1.9$ & Loeng et al. (1997) \\
\hline $\begin{array}{l}\text { Eastern EB }\left(78^{\circ} 31^{\prime} \mathrm{N}\right. \\
\left.\text { and } 133^{\circ} 58^{\prime} \mathrm{E}\right)\end{array}$ & 1995-1996 & $\begin{array}{l}\text { net transport in the } \\
\text { upper } 1200 \mathrm{~m} \text { layer }\end{array}$ & $5 \pm 1$ & Woodgate et al. (2001) \\
\hline
\end{tabular}

based observations carried out between 1997 and 2010 suggest a net (for all waters) transport by the WSC as high as $6.6 \pm 0.4 \mathrm{~Sv}$ (here and further throughout the text, values after \pm signs indicate the standard error of the mean except for the correlation coefficients for which they indicate the range of the $95 \%$ confident interval). In Fram Strait, the WSC consists of three branches - the WSC core branch, the offshore branch, and the WSC recirculation branch. The overall transport of warm AW toward the Arctic Ocean for these three branches is approximately $3.0 \pm 0.2 \mathrm{~Sv}$ (Table 1). About $1.3 \pm 0.1 \mathrm{~Sv}$ of the AW transport is carried by the topographically steered core branch of the WSC (annual mean transports vary in the range of 1.0-1.5 Sv). North of Fram Strait, this branch turns to the east and follows along the Svalbard northern slope further into the Arctic Ocean (see Fig. 1 for details). About $1.7 \pm 0.1 \mathrm{~Sv}$ of the AW transport in Fram Strait is carried by the highly variable (annual mean transports vary in the range of 1-2 Sv) offshore WSC branch - the branch which feeds the flow toward the Yermak Plateau. The large difference between the total transport in the West Spitsbergen Current and net AW inflow into the Arctic Ocean suggests substantial recirculation of the AW in the strait and in the surrounding region (Schauer et al., 2008; Beszczynska-Möller et al., 2012; Hattermann et al., 2016). Multiyear means of the AW inflow $\left(T>1.5^{\circ} \mathrm{C}\right.$; allowing for some heat loss between the mooring line in Fram Strait and the Yermak Plateau) crossing Yermak Plateau estimated from an operational model system are in agreement with the values given above (Koenig et al., 2017).

Several snapshot-based estimates of volume transports are available for the slope area of Svalbard. Despite the very different timescales of snapshot-based and long-term estimates of transports, the former provide useful information about the possible ranges in transport variability. For example, Våge et al. (2016) - using geostrophic velocities at two CTD cross sections across the boundary current flow near $30^{\circ} \mathrm{E}$ in 2012 - reported a net AW transport of $1.6 \pm 0.3 \mathrm{~Sv}$ (Table 1). The authors found evidence of a large warm-core (anti-cyclonic) eddy north of the main core of the boundary current potentially affecting the mean volume transport calculations.

All above estimates of transports are sensitive to the definition of the AW. Based on multiple cross-slope CTD sections in the area between 21 and $33^{\circ} \mathrm{E}$ in 2013, Pérez-Hernández et al. (2017) - using density- and salinity-based criteria defining the AW $\left(27.7<\sigma<27.97 \mathrm{~kg} \mathrm{~m}^{-3}\right.$ and $\left.S>34.9\right)$ - estimated AW transport as $2.31 \pm 0.29 \mathrm{~Sv}$ (Table 1). The authors also found large differences (from $0.53 \pm 0.16$ to $3.39 \pm 0.25 \mathrm{~Sv}$ ) in transports amongst different transects conducted during their September survey, providing further evidence that the potential impact of eddies and meanders to these transports can be substantial.

The inflow of the Barents Sea water is thought to be the second potential forcing affecting the Laptev Sea transports; however, information about this inflow is very limited. Based on year-long mooring observations collected in the strait between Franz Josef Land and Novaya Zemlya, the net volume transport of Barents Sea AW was estimated as $\sim 1.9 \mathrm{~Sv}$ (Loeng et al., 1997; Table 1). Unfortunately, we cannot verify the changes in these AW forcings along the EB slope to the east of St. Anna Trough, as there are no long-term observations of boundary current velocities that can be used for the assessment of ACBC transports. Observations of currents at several sites near Novaya Zemlya and the central Laptev Sea slopes in 2002-2012 have been derived from single moorings; these are not suitable for transport calculations, even if the period of observations was long enough to provide insight for the long-term structure of the boundary current there (e.g., Pnyushkov et al., 2013, 2015). However, in the eastern part of the EB, at the junction of the Lomonosov Ridge with the continental slope, Woodgate et al. (2001) estimated water transports using year-long velocity mooring records from 1995-1996. With some a priori assumptions regarding the spatial structure of the ACBC between moorings, they estimated that the boundary current transports approximately 
$5 \pm 1 \mathrm{~Sv}$ in the upper $\sim 1200 \mathrm{~m}$ (i.e., within the layer spanned by velocity observations at moorings; Table 1 ).

\section{Observational data}

\subsection{Mooring observations and CTD surveys}

In order to estimate transports in the eastern EB of the Arctic Ocean, we used observations collected in 2013-2015 at six moorings distributed across the Laptev Sea continental slope (Fig. 2). These moorings, deployed along the $125^{\circ} \mathrm{E}$ meridian in September 2013 as a part of the NABOS program, were designed to provide a detailed picture of the structure and variability of the ACBC in this region (Polyakov et al., 2007; details on the observational program can be found at the project website - http://nabos.iarc.uaf.edu/, last access: March 2018). The continental slope at the central Laptev Sea is gentle (bottom slope is $\sim 350 \mathrm{~m}$ per $10 \mathrm{~km}$ ), resulting in a lateral stretching of the ACBC. For an accurate description of the spatial ACBC pattern, the moorings were unevenly distributed across the slope, with shorter distances between the more shallow moorings. For example, the distance between moorings $\mathrm{M} 1_{1}$ and $\mathrm{M} 1_{2}$ was approximately $11 \mathrm{~km}$, which is only $4 \mathrm{~km}$ larger than the first baroclinic Rossby radius of deformation estimated for the eastern EB (Nurser and Bacon, 2014). In the deep basin the distance increases to $170 \mathrm{~km}$ between $\mathrm{M}_{4}$ and $\mathrm{M}_{5}$ (Fig. 2). All moorings were successfully recovered in September 2015, providing a unique set of 2-year-long records of velocity, temperature, and salinity observations. Summer mooring deployments and recoveries were accompanied by hydrographic surveys using an SBE 911plus CTD profiler. These surveys provided detailed maps (with distances between CTD stations varying from $\sim 5$ to $170 \mathrm{~km}$ ) of the cross-slope structure of water properties at the Laptev Sea slope and adjacent regions.

Each mooring was equipped with instruments measuring horizontal velocities, temperatures, and conductivities (see mooring schematics in Fig. 2 for details). Velocity observations were collected using McLane Moored Profilers (MMPs) and acoustic Doppler current profilers (ADCPs). The MMPs operated between $\sim 80$ and $780 \mathrm{~m}$ of depth every other day, with a vertical resolution of approximately $0.25 \mathrm{~m}$. Moving up and down along the mooring line at a mean rate of $\sim 25 \mathrm{~cm} \mathrm{~s}^{-1}$, it takes less than $1 \mathrm{~h}$ for the MMP to measure the entire vertical profile within the above depth range. The relatively short period of time required for the MMP to complete a single vertical profile suggests that each profile represents a snapshot of the hydrography and velocity at the mooring location. Each MMP was equipped with a high-resolution $\left(<0.01 \mathrm{~cm} \mathrm{~s}^{-1}\right)$ FSI (Falmouth Scientific Inc.) acoustic current meter (ACM) sensor capable of measuring 2-D current velocities using the phase difference between upstream and downstream acoustic signals. Temperature, conductivity, and velocity sensors installed onboard the MMPs were calibrated by the MMP manufacturer before deployment in 2013.

All raw MMP data were processed using Woods Hole Oceanographic Institution (WHOI) software. During processing, the original measurements were averaged over 2 dbar pressure bins (the weights of the individual measurements were determined based on the pressure distribution within each bin). After averaging, the error of the binaveraged velocities was approximately 3 times smaller when compared to the instrumental ACM error $(\sim 1 \%$ of the ACM reading $\left.\pm 0.5 \mathrm{~cm} \mathrm{~s}^{-1}\right)$. In addition, raw MMP compass readings were corrected for the horizontal compass bias.

Seven upward-looking ADCPs also measured current velocities at the moorings. At all moorings except $\mathrm{M}_{1}$, the $300 \mathrm{kHz}$ ADCPs were deployed at depths ranging from 55 to $80 \mathrm{~m}$ to provide measurements of current velocities within the upper ocean layer. The uppermost $\sim 6-10 \mathrm{~m}$ layer was left blank due to the interference of acoustic signals near the ocean surface. Additionally, $75 \mathrm{kHz}$ ADCPs were installed at the two moorings $\mathrm{M} 1_{1}$ and $\mathrm{M} 1_{4}$ that measured velocities in the layers of 5-245 and $180-450 \mathrm{~m}$, respectively. The ADCP records did not overlap the MMP measurements (Fig. 2). ADCP measurements were averaged over $2 \mathrm{~m}$ $(300 \mathrm{kHz}$ ADCP) or $5 \mathrm{~m}(75 \mathrm{kHz}$ ADCP) vertical cells, with $1 \mathrm{~h}$ time resolution.

In order to reduce the effect of measurement errors and to remove the tidal and inertial components of currents that dominate variability in the upper ocean layer in this region (Pnyushkov and Polyakov, 2012), we averaged the hourly ADCP observations into daily records.

The magnetic inclinations determined from the International Geomagnetic Reference Field for the mooring positions (see https://www.ngdc.noaa.gov/IAGA/vmod/, last access: March 2018) were added to the raw readings of the magnetic compass of each instrument. The instrumental accuracy of the MMP magnetic compass is $2^{\circ}$. The manufacturer estimates for 75 and $300 \mathrm{kHz}$ ADCP accuracies are $0.5 \%$ of measured speed and $2^{\circ}$ for current direction. However, due to the weak horizontal geomagnetic field strength in the EB, the individual compass error may substantially exceed the instrumental accuracy (errors may be as high as $\sim 30^{\circ}$; Thurnherr et al., 2017). These errors are individual for each instrument and cannot be quantified without concurrent (nonmagnetic) measurements of current directions. Unfortunately, our moorings were not equipped with the instruments which could measure current directions that way, and, thus, we cannot provide more reliable estimates of the compass errors.

For each mooring, we merged the MMP and ADCP records into one dataset that was further used to calculate transports. Replicating the temporal resolution of the filtered (low-passed) ADCP records, this dataset has a daily temporal resolution. Bi-daily MMP profiles were linearly interpolated in time to match the final temporal resolution. In the merged dataset, each of the velocity profiles was accompanied by 
temperature and salinity profiles collected by the MMP and SBE 37 instruments (see Fig. 2 for details on mooring instrumentation). Data gaps in temperature, salinity, and velocity profiles in the layers between instruments were filled using vertical linear interpolation.

Due to time averaging, daily low-passed ADCP profiles contain less noise compared with snapshot bi-daily MMP velocity profiles. After averaging over the length of 20132015 records, the largest $\left(\sim 0.3 \mathrm{~cm} \mathrm{~s}^{-1}\right)$ standard error of the mean velocity was observed at mooring $\mathrm{M1}_{3}$. A sensitivity test was conducted to assess how the merging of datasets with different temporal resolutions and noise levels affects the estimates of net volume transports. In this test, for moorings equipped with MMPs (i.e., for $\mathrm{M}_{2}, \mathrm{M}_{3}, \mathrm{M}_{5}$, and $\mathrm{M} 1_{6}$ moorings) daily ADCP velocity profiles were replaced with snapshot measurements carried out by the ADCPs at times approximately matching the MMP snapshot measurements. Using this dataset, we estimated the net (within the upper $780 \mathrm{~m}$ layer) volume transport and found that the net eastward volume transport varied insignificantly $(<5 \%)$.

We complement our analysis of mooring-based observations with an extensive dataset of temperature and salinity observations collected from various expeditions in the eastern EB of the Arctic Ocean over the 2000-2015 period to estimate the cross-slope structure of water masses over the EB slope (Sect. 4.1). This dataset was used, for example, in previous studies of long-term changes in the thermohaline state of the EB (Polyakov et al., 2008, 2012) and the structure of the ACBC (Pnyushkov et al., 2015). We note that the dataset was recently updated with CTD observations from two shipbased surveys, which accompanied the deployments and recoveries of moorings in 2013 and 2015 (see NABOS web page at nabos.iarc.uaf.edu), and ice-tethered profiler (ITP) data (available at http://www.whoi.edu/page.do?pid=20756, last access: March 2018). This dataset provides important information about temperature and salinity distributions across the continental slope of the Laptev Sea and fills the gaps in the upper ocean layer, which was only partially covered by 2013-2015 mooring observations. All oceanographic measurements have been made using CTD instruments with high accuracy for temperature $\left(0.001^{\circ} \mathrm{C}\right)$ and salinity $(0.003)$.

\subsection{Methods of analysis}

Here, we provide details on the methods used in this study to calculate current persistence and geostrophic velocities as well as the volume, heat, and salt transports.

\subsubsection{Persistence of currents}

To quantify the persistence (or stability) of current directions at the Laptev Sea slope, we calculated the number of days in the 2-year records when daily currents fell into a specific directional bin. Each of these bins represents currents within a $12^{\circ}$ angular sector. The width of these sectors is substan- tially wider than the reported instrumental accuracy of measurements for current directions, but may be comparable with those due to the weak horizontal magnetic field. In addition, we decomposed velocity records for the mean and variable currents and calculated ellipses of standard deviations (SDs) for the depth-averaged flow.

\subsubsection{Geostrophic currents}

For estimates of the cross-sectional baroclinic geostrophic velocities (geostrophic shear velocities; $u_{\mathrm{s}}$ ), we applied the thermal wind equations to the 2013-2015 mean potential densities provided by mooring measurements. The same method was implemented in our previous studies of the structure and variability of the ACBC at the Laptev Sea slope (see Pnyushkov et al., 2013, 2015, for details). In these calculations, however, we do not assume a level of no motion because during the 2013-2015 period, the mean velocity profiles show no evident levels with zero velocities. This is likely due to a substantial barotropic flow at the Laptev Sea slope. Instead, we estimate the barotropic flow from the mooring records. Specifically, we calculate the depth average of eastward velocity for each mooring and average this barotropic velocity between each pair of moorings $\left(u_{\mathrm{b}}\right)$. We then add this to the baroclinic geostrophic velocity calculated from the thermal wind relation so that the total geostrophic currents were calculated as $u_{\mathrm{g}}=u_{\mathrm{b}}+u_{\mathrm{s}}$.

\subsubsection{Depth-integrated transports}

Individually for each mooring, we vertically integrated the eastward velocities $u(z)$ to obtain water transport $\left(D_{\mathrm{W}}\right.$, $\mathrm{m}^{2} \mathrm{~s}^{-1}$ ), products of temperature anomaly $T(z)-T_{\text {ref }}$ and velocity $\left(D_{\mathrm{H}}, \mathrm{W} \mathrm{m}^{-1}\right)$ to obtain heat transport, and products of salinity anomaly $S(z)-S_{\text {ref }}$ and velocity $\left(D_{\mathrm{S}}, \mathrm{kg} \mathrm{m}^{-1} \mathrm{~s}^{-1}\right)$ to obtain salt transport (which we will call further depthintegrated transports).

$$
\begin{aligned}
D_{\mathrm{W}}=\int_{z_{1}}^{z_{\text {up }}} u(z) \mathrm{d} z \approx \sum_{j} 0.5\left(u_{j}+u_{j+1}\right)\left(z_{j+1}-z_{j}\right), \\
\quad z_{1} \leq z_{j} \leq z_{\text {up }}
\end{aligned}
$$

$$
\begin{aligned}
D_{\mathrm{H}}= & \int_{z_{1}}^{z_{\text {up }}} \rho c_{p} u(z)\left(T(z)-T_{\mathrm{ref}}\right) \mathrm{d} z \approx \sum_{j} 0.5 \rho c_{p} \\
& {\left[u_{j}\left(T_{j}-T_{\mathrm{ref}}\right)+u_{j+1}\left(T_{j+1}-T_{\mathrm{ref}}\right)\right]\left(z_{j+1}-z_{j}\right), } \\
& z_{l} \leq z_{j} \leq z_{\text {up }}
\end{aligned}
$$

and 


$$
\begin{aligned}
D_{\mathrm{S}}= & \int_{z_{1}}^{z_{\text {up }}} \rho u(z)\left(S(z)-S_{\mathrm{ref}}\right) \mathrm{d} z \approx \sum_{j} 0.5 \rho \\
& {\left[u_{j}\left(S_{j}-S_{\text {ref }}\right)+u_{j+1}\left(S_{j+1}-S_{\text {ref }}\right)\right]\left(z_{j+1}-z_{j}\right), } \\
& z_{1} \leq z_{j} \leq z_{\text {up }},
\end{aligned}
$$

where $z_{1}$ and $z_{\text {up }}$ are the lower and upper limits of integration, $c_{p}$ is the specific heat of seawater, and $\rho$ is the in situ water density; $u_{j}, T_{j}$, and $S_{j}$ are the eastward velocity, temperature, and salinity measured at the level $z_{j}$, respectively. All these depth-integrated transports have simple physical meanings. For example, $D_{\mathrm{w}}$ represents water transport within the specified depth range through a unit segment of mooring section. The integral of $D_{\mathrm{w}}$ over the length of the mooring section provides the net volume transport. To calculate the products of temperature and salinity anomalies and velocities, available temperature and salinity profiles were interpolated to the levels of velocity measurements using linear interpolation. The transports of heat and salt were estimated using the freezing point $T_{\text {ref }}=-1.8^{\circ} \mathrm{C}$ as the reference temperature and $S_{\text {ref }}=0$ as the reference salinity. For calculations of the AW depth-integrated transports, $z_{1}$ and $z_{\text {up }}$ were determined as the shallowest and deepest levels with positive $\left(T>0{ }^{\circ} \mathrm{C}\right)$ water temperatures. If positive temperatures reached the deepest level of observations we used the latter as the lower limit of integration. $D_{\mathrm{W}}, D_{\mathrm{H}}$, and $D_{\mathrm{S}}$ at mooring $\mathrm{M}_{4}$ were estimated using extrapolated current velocities from $453 \mathrm{~m}$ (the deepest level of current observations) to the last CTD level $(795 \mathrm{~m})$ to extend data coverage within the AW layer. While extrapolating currents, we assume a barotropic vertical structure of the ACBC flow below $453 \mathrm{~m}$ so that all the extrapolated velocities were equal to the value measured at the deepest level with observations. The assumption of the barotropic vertical structure at mooring $\mathrm{M}_{4}$ is supported by velocity measurements from previous (20022011) years and by our estimates of geostrophic velocity in which the deviations from the uniform (barotropic) vertical profile below $450 \mathrm{~m}$ do not exceed $0.2 \mathrm{~cm} \mathrm{~s}^{-1}$, or $\sim 10 \%$ of the mean current at the mooring site.

In order to evaluate the limitations of this extrapolation in a quantitative way, we used velocity and temperature profiles consisting of depths ranging from $80-900 \mathrm{~m}$ at the $\mathrm{M} 1_{4}$ mooring site collected by the MMP instrument in 2004 2005 . Using these profiles, we calculated $D_{\mathrm{H}}$ twice, once with original currents and again with extrapolated currents below $450 \mathrm{~m}$, and compared the results. We found that the difference between the two $D_{\mathrm{H}}$ estimates was small and did not exceed $5 \%$.

\subsubsection{Along-slope transports}

The property transports $\left(F_{\mathrm{W}}, F_{\mathrm{H}}\right.$, and $\left.F_{\mathrm{S}}\right)$ along the Laptev Sea section were estimated by horizontally integrating the depth-integrated transports over the length $L$ of the mooring transect (referred to as transports further in the text).

$$
\begin{gathered}
F_{\mathrm{W}}=\int_{(L)} D_{\mathrm{W}} \mathrm{d} l \approx \sum_{i=1}^{5} 0.5\left(D_{\mathrm{W}_{i}}+D_{\mathrm{W}_{i+1}}\right) \Delta l_{i, i+1}, \\
{\left[\mathrm{~m}^{3} \mathrm{~s}^{-1} \text { or } \mathrm{Sv} ; 1 \mathrm{~Sv}=10^{6} \mathrm{~m}^{3} \mathrm{~s}^{-1}\right],}
\end{gathered}
$$

$$
F_{\mathrm{H}}=\int_{(L)} D_{\mathrm{H}} \mathrm{d} l \approx \sum_{i=1}^{5} 0.5\left(D_{\mathrm{H}_{i}}+D_{\mathrm{H}_{i+1}}\right) \Delta l_{i, i+1},[\mathrm{~W}],
$$

and

$$
F_{\mathrm{S}}=\int_{(L)} D_{\mathrm{S}} \mathrm{d} l \approx \sum_{i=1}^{5} 0.5\left(D_{\mathrm{S}_{i}}+D_{\mathrm{S}_{i+1}}\right) \Delta l_{i, i+1},\left[\mathrm{~kg} \mathrm{~s}^{-1}\right],
$$

where $i$ indicates the mooring number starting from the shallowest mooring $\mathrm{M}_{1} ; \Delta l_{i, i+1}$ is the distance between the two neighboring moorings designated by $i$ and $i+1$.

The net transport was estimated for the entire area covered by mooring observations. For AW the integration was performed within the area spanned by this water mass. The AW transport uncertainty due to limited data coverage can be estimated if we extrapolate mooring velocities downward to the lower boundary of the AW (as determined by CTD profiles during mooring deployments and recoveries in 2013 and 2015). Applying the assumption of barotropic (depthuniform) vertical structure of the currents in this depth range, the inferred AW heat transport will increase by $\sim 18 \%$ (note that this number may change if using an alternate $T_{\text {ref }}$ ). This number provides a very rough estimate of the uncertainty for the AW transport due to incomplete data coverage.

Following the terminology widely accepted in oceanographic studies (e.g., Woodgate et al., 2006, 2010; Johns et al., 2011; Li et al., 2017), we used the terms "heat" and "salt" transports to describe advective transports of water properties carried by the boundary current over the Laptev Sea section. However, we note that in the case of unclosed volume balance when the advected mass is not conserved, $F_{\mathrm{H}}$ and $F_{\mathrm{S}}$ mean temperature and salinity anomaly transports calculated relative to the reference values; only when the mass transport is balanced do these temperature and salinity anomaly transports have an unambiguous physical interpretation as heat and salt transports. This limitation suggests that our estimates of heat and salt transports are valid only for the specific volume of water advected through the Laptev Sea section in 2013-2015. We also note that the results of heat and salt transport calculations are sensitive to the choice of $T_{\text {ref }}$

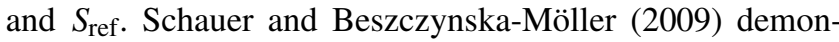
strated that the uncertainty in the heat transports may be of the same order of magnitude as the signal itself. A similar dependence on $S_{\text {ref }}$ occurs in calculations of freshwater transports (see Tsubouchi et al., 2012; Carmack et al., 2016, for 
discussion). The requirement for mass conservation cannot be satisfied using observations from one cross-slope section; thus, our estimates for heat and salt transports are subject to uncertainty caused by an arbitrary choice of $T_{\text {ref }}$ and $S_{\text {ref. }}$. However, our choice for $T_{\text {ref }}$ does have a clear physical meaning - the temperature below which seawater cannot exist as a liquid. Another reason for choosing the freezing temperature as $T_{\text {ref }}$ is that the heat content of the SML in winter is limited by this physical boundary. $S_{\text {ref }}=0$ is also a reasonable choice, indicating the salt content in seawater; with that choice of $S_{\text {ref }}$ the calculated salt transport has an unambiguous physical meaning even for a nonzero net volume transport. Despite limitations, our estimates have utility. In the case of using different $T_{\text {ref }}$ and $S_{\text {ref }}$, estimates for heat and salt transports can be recalculated using a simple linear relationship originally suggested by Carmack et al. (2016) for freshwater fluxes. We note that the suggested relationship is also valid for heat and salt transports due to its linear nature relative to the reference values.

\subsubsection{Heat transport density}

We approach the problem of the sensitivity of heat transports to the choice of $T_{\text {ref }}$ for the case of unclosed mass balance by evaluating the heat transport density:

$$
\begin{aligned}
F_{\mathrm{HN}}= & \frac{\int_{(L)} D_{\mathrm{H}} \mathrm{d} z}{\int_{(L)} D_{\mathrm{W}} \mathrm{d} z} \approx \frac{\int_{z_{1}}^{z_{2}} \rho c_{p} u(z) T(z) \mathrm{d} z}{\int_{z_{1}}^{z_{2}} u(z) \mathrm{d} z}-\rho c_{p} T_{\mathrm{ref}}, \\
& {\left[\mathrm{W} \mathrm{s} \mathrm{m}^{-3} \text { or TW Sv } \mathrm{TW}^{-1}\right] . }
\end{aligned}
$$

$F_{\mathrm{HN}}$ is the amount of heat transported by a unit of water transport and is always related to a constant water transport. More generally, $F_{\mathrm{HN}}$ quantifies the heat content transported by the mean current. As it follows from Eq. (7), a change in $T_{\text {ref }}$ shifts the mean of the entire $F_{\mathrm{HN}}$ series, keeping the shape of the series intact. Therefore, for the assessment of the temporal variability of the heat transports, using $F_{\mathrm{HN}}$ is insensitive to the choice of $T_{\text {ref }}$ and is thus a more robust compared to an assessment made with $F_{\mathrm{H}}$. In this study, we use both $F_{\mathrm{H}}$ and $F_{\mathrm{HN}}$ to quantify heat fluxes.

\section{Water mass and flow structures over the Laptev Sea slope in 2013-2015}

In this section, we document the vertical thermohaline and dynamic structures of waters at the continental slope of the Laptev Sea using temperature, salinity, and velocity profiles measured at the mooring array along the $125^{\circ} \mathrm{E}$ section in 2013-2015, together with ship-based CTD measurements. Special attention is paid to the distribution of $\mathrm{AW}$ as the major contributor to water mass structure in the eastern EB.

\subsection{Water mass structure over the Laptev Sea slope}

In 2013-2015, the AW occupied an intermediate layer between $\sim 80$ and $\sim 1000 \mathrm{~m}$ (Fig. 3). On average, this water occupied $\sim 80 \%$ of the upper $780 \mathrm{~m}$ layer at the $125^{\circ} \mathrm{E}$ section covered by the 2013-2015 mooring measurements. Comparison of the 2013-2015 mean temperatures against the PHC climatological temperatures for the early 1990s at the three deepest moorings $\left(\mathrm{M}_{4}, \mathrm{M}_{5}\right.$, and $\left.\mathrm{M}_{6}\right)$ suggests a substantially warmer $\left(>0.5^{\circ} \mathrm{C}\right) \mathrm{AW}$ core in recent years, in agreement with earlier findings (e.g., Polyakov et al., 2013; Figs. 2 and 3a). The vertical position of AW boundaries in 2013 2015 is also changed when compared with PHC climatology. The average depth of the AW upper boundary (defined by the $0{ }^{\circ} \mathrm{C}$ isotherm) was at $\sim 125 \mathrm{~m}$ of depth (shown as red dashed lines in Fig. 3a and b), which is $\sim 50 \mathrm{~m}$ shallower than in the climatology. However, this boundary varied seasonally and spatially across the slope. For example, substantial seasonal displacement of the upper AW boundary was registered at mooring $\mathrm{M1}_{4}$ (2700 $\mathrm{m}$ bottom depth), where it varied from $\sim 85 \mathrm{~m}$ in January to $\sim 170 \mathrm{~m}$ in early July (not shown). At mooring $\mathrm{M}_{2}(787 \mathrm{~m})$, the upper AW boundary was significantly deeper, at $\sim 200 \mathrm{~m}$ on average, but descending to $\sim 350--400 \mathrm{~m}$ in the middle of summer. At the shallowest mooring $\mathrm{M1}_{1}$ (250 $\mathrm{m}$ of depth), AW was only present during a short period ( $<15$ days) in winter of both years. This suggests that on average, the lateral AW boundary over the upper slope in 2013-2015 was located between the $\mathrm{M} 1_{1}$ and $\mathrm{M1}_{2}$ moorings.

At the three deep moorings $\mathrm{M1}_{4}, \mathrm{M}_{5}$, and $\mathrm{M} 1_{6}$, the AW extends deeper than the last observational level $(\sim 780 \mathrm{~m})$. Ship-based CTD profiles from 2002-2015 along the $125^{\circ} \mathrm{E}$ line suggest that the mean position of the lower AW boundary is $\sim 800 \mathrm{~m}$, which is close to the deepest observational level at NABOS moorings, but can vary significantly (down to $\sim 1000 \mathrm{~m}$ ) in some years. The relatively small differences between the deepest observational level at moorings and the lower AW boundary determined from the 2002-2015 CTD casts at mooring sites suggest that our 2013-2015 records include observations within 80 to $98 \%$ of the AW layer, thus providing sufficient data coverage to describe water properties in this layer.

In 2013-2015, the AW temperature core as determined by the in situ temperature maximum $(\sim 220 \mathrm{~m})$ was found at mooring $\mathrm{M}_{5}$ (Fig. 3). The AW core temperature averaged over the length of the mooring record was $\sim 1.6^{\circ} \mathrm{C}$. AW temperature decreased gradually from the core toward both the shelf and deep basin. Temperature and salinity decrease much faster over the upper slope between the $\mathrm{M} 1_{3}$ and $\mathrm{M}_{2}$ moorings. Higher spatial gradients of temperature and salinities between these moorings indicate the likely existence of a strong hydrographic front separating waters from different origins, consistent with findings reported in Bauch et al. (2009). This front was evident, for instance, in the average distribution of 2013-2015 potential density, in which the 

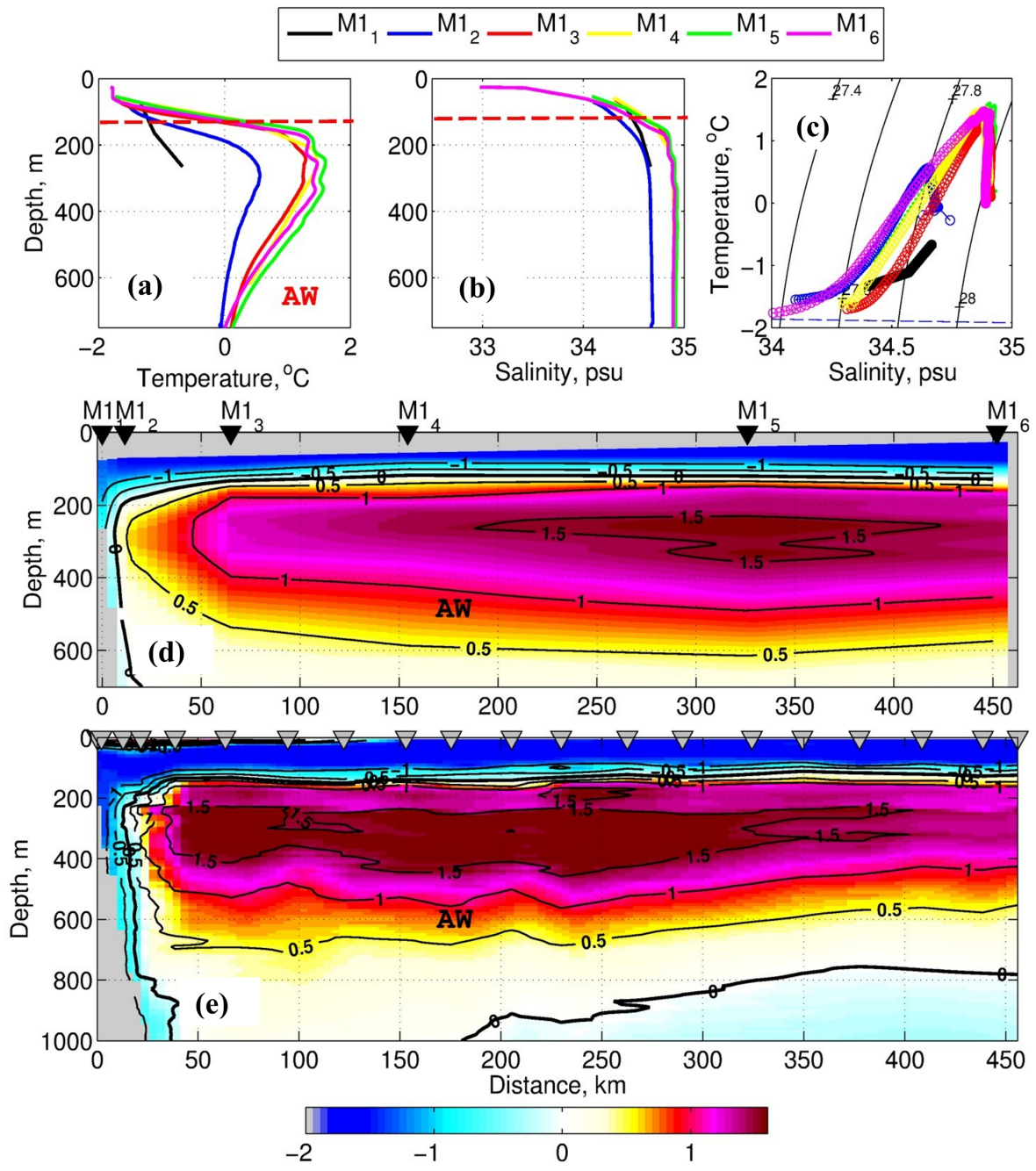

Figure 3. The 2013-2015 mean (a) temperature ( $T$ ) and (b) salinity $(S)$ profiles and (c) $T-S$ diagrams from the mooring array deployed at the Laptev Sea slope. Red dashed lines show the position of the AW upper boundary. Mean temperature distribution along the $125^{\circ} \mathrm{E}$ section from (d) the 2013-2015 mooring observations and (e) 2013 summer CTD section. Black thick lines in (d) and (e) show the boundaries of the AW layer. Gray triangles in (e) show the positions of CTD stations in 2013.

average density gradients were as high as $0.26 \mathrm{~kg} \mathrm{~m}^{-3}$ per $100 \mathrm{~km}$ (Fig. 4, lower panel; see Baumann et al., 2018, for further details).

Summarizing, we note that at least $80 \%$ of the area covered by mooring observations in the upper $780 \mathrm{~m}$ layer of the Laptev Sea slope is occupied by the AW, making it the dominant water mass there. However, the contribution from this water varies across the slope from negligible at the upper slope (at the site of $\mathrm{M} 1_{1}$ mooring) to dominant at the deep part of the slope, where it occupies up to $\sim 90 \%$ (at the $\mathrm{M} 1_{4}$ mooring site) of the water column between the surface and $780 \mathrm{~m}$ of depth. The slope segments with dominant and weak AW contributions are separated by the hydrographic front found between $\mathrm{M}_{2}$ and $\mathrm{M}_{3}$.

\subsection{Cross-slope pattern of velocities}

The unique set of velocity records collected at the EB continental slope allows for a comprehensive analysis of the spatial structure of the boundary current. We further assess the cross-slope pattern of the ACBC at the Laptev Sea slope using velocity profiles averaged over the record for all mooring sites (Fig. 4).

This analysis suggests that mean current directions agree well with the local topography of the Laptev Sea slope. For instance, the 2013-2015 mean currents generally follow the isobaths with shallow-to-right direction; depths are from a 2 min global array of bottom topography (https://www.ngdc. noaa.gov/mgg/global/etopo2.html, last access: March 2013; Fig. 5). The agreement between mean current directions and topography is a known feature of a barotropic flow (Ped- 


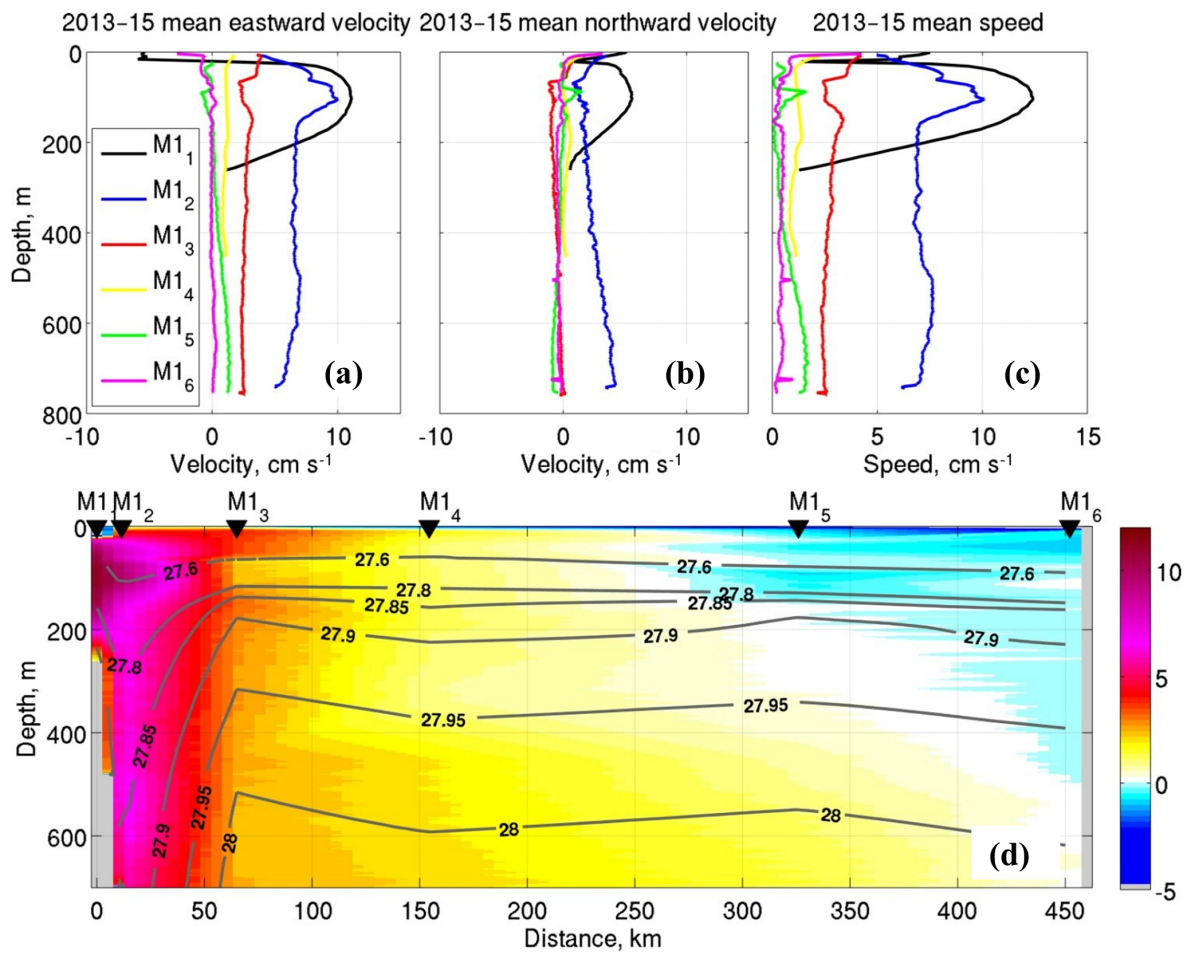

Figure 4. (a) Eastward and (b) northward velocities and (c) current speed at six moorings deployed at the Laptev Sea slope in 2013-2015; (d) distribution of the mean eastward velocity along the $125^{\circ}$ E section. Gray contours show mean potential density calculated using $2013-$ 2015 temperature and salinity observations at moorings.

losky, 1990), suggesting that mean (large-scale) circulation in the upper $780 \mathrm{~m}$, including the AW layer in the eastern $\mathrm{EB}$, is likely controlled by barotropic factors. The uniform vertical structure of the 2013-2015 mean velocity profiles below $250 \mathrm{~m}$ at five deep moorings (except the shallow-water $\mathrm{M} 1_{1}$ mooring) supports our conclusion that the flow at the Laptev Sea slope is predominantly barotropic. The only exception is the cold halocline and the upper AW layers (above $200 \mathrm{~m}$ ), where a substantial (up to $3 \mathrm{~cm} \mathrm{~s}^{-1}$ ) baroclinic velocity maximum was found (Fig. 4a).

In agreement with the predominantly east-west orientation of isobaths at the central Laptev Sea slope, the zonal component of depth-averaged currents prevails over the meridional component for all moorings except $\mathrm{M}_{6}$ (Figs. 4 and 5). As a result, we will refer to the zonal component of currents and transports as along-slope; the meridional component will be referred to as cross-slope. At $\mathrm{M}_{6}$, mean currents were directed approximately southward (Fig. 5). This southward direction for the mean currents at mooring $\mathrm{M}_{6}$ agrees with the pattern of AW circulation suggested by Rudels et al. (1994), who hypothesized the existence of cyclonic recirculation within the Amundsen Basin and the southward return branch of the AW along the Gakkel Ridge. This southward direction also agrees well with the distribution of bottom topography in which the flow goes along isobaths, similar to other moorings. The predominantly south- ward direction of the mean currents at this mooring suggests that the boundary of the near-slope ACBC is somewhere between moorings $\mathrm{M}_{5}$ and $\mathrm{M}_{6}$.

The cross-slope distribution of mooring velocities shows a strong weakening of along-slope currents from the Laptev Sea shelf toward the deep ocean from a maximum velocity of $\sim 11 \mathrm{~cm} \mathrm{~s}^{-1}$ at the shallowest mooring $\left(\mathrm{M}_{1}\right)$, to $\sim$ $0.5 \mathrm{~cm} \mathrm{~s}^{-1}$ at mooring $\mathrm{M}_{5}$, and even to negative values at $\mathrm{M} 16$ (Fig. 4). The strongest (2-fold) reduction of velocities (from $\sim 5$ to $2 \mathrm{~cm} \mathrm{~s}^{-1}$ ) at the shallow part of the Laptev Sea slope between the $\mathrm{M}_{2}$ and $\mathrm{M}_{3}$ moorings is accompanied by significant density changes associated with the hydrographic front (Fig. 4d).

Although mooring observations suggest a gradual decrease in eastward velocities from the shelf toward the deep ocean, the actual ACBC structure may have a more complex cross-slope pattern, which is not captured by the coarse mooring spacing. Simulations performed with the OCCAM (Ocean Circulation and Climate Advanced Modeling) numerical model suggest a multicore ACBC structure in the EB (Aksenov et al., 2011). For example, the cross-slope distribution of simulated current velocities in the central Laptev Sea (along $126^{\circ} \mathrm{E}$ ) demonstrates the existence of two separate velocity cores evident in the eastward velocity component; one core is simulated above the lower part of the continental slope over the $\sim 3000 \mathrm{~m}$ isobaths (near the $\mathrm{M}_{4}$ moor- 

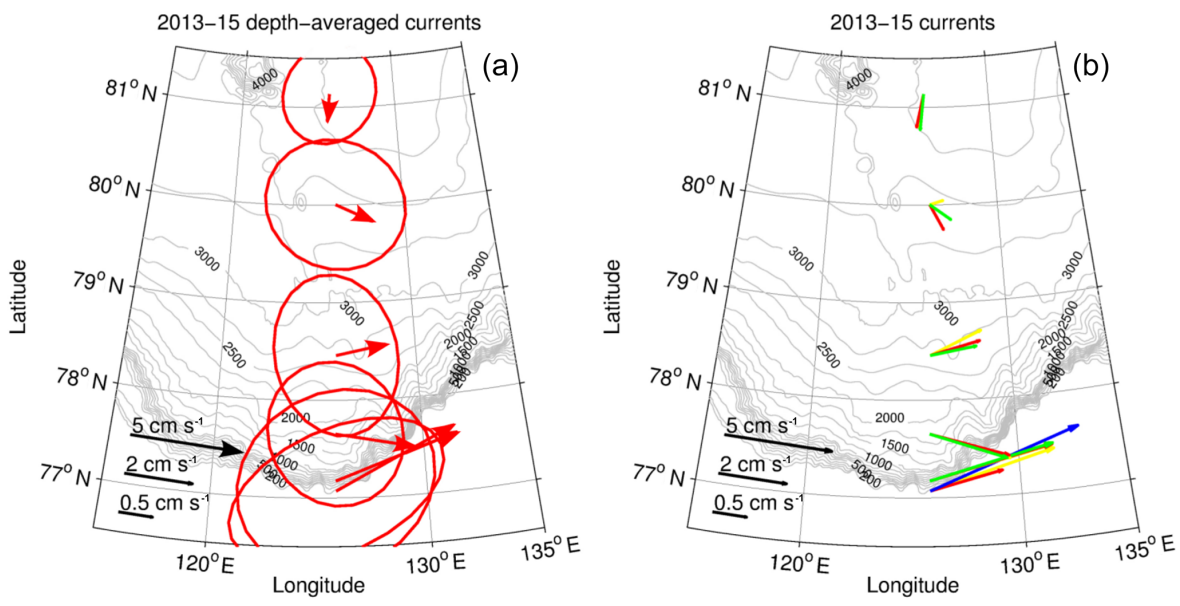

Figure 5. (b) The 2013-2015 mean current vectors at 150 (blue), 200 (yellow), 250 (red), and $300 \mathrm{~m}$ (green), with (a) their depth-averaged $(0-780 \mathrm{~m})$ means. Gray contours show isobaths. Red ellipses with the centers at mooring sites represent ellipses of the standard deviations of the depth-averaged currents. A nonlinear scale is used to show vectors and ellipses.

ing site), while the second core is over the model continental shelf break at the $\sim 400 \mathrm{~m}$ isobaths (see Fig. 8 in Aksenov et al., 2011). The velocity core over the deepest part of the continental slope was simulated within a depth range of $\sim 200-400 \mathrm{~m}$ and is associated with the Fram Strait branch of the AW. The shallower branch transports Arctic halocline water, with negative water temperatures, along the EB slope within the $\sim 100-200 \mathrm{~m}$ layer (Aksenov et al., 2011). We note here that Aksenov et al. (2011) suggested the existence of an additional BC core associated with Barents Sea Deep Water, which was formed by Barents Sea winter convection and located at $\sim 900 \mathrm{~m}$ of depth. However, available $2013-$ 2015 mooring records cannot confirm the suggested structure due to their limited spatial coverage.

The strongest velocity decrease at the hydrographic front suggests that the density distribution is firmly linked to the circulation in the intermediate layer in the eastern EB. For the area covered by deep mooring observations (at moorings $\mathrm{M} 1_{4}-\mathrm{M} 1_{6}$ ), the magnitudes of geostrophic currents contribute up to $80 \%$ of the total current speed, suggesting that the thermal wind relationship is a good approximation in this region (Fig. 6). We complemented our estimates of the geostrophic currents over the Laptev Sea slope with their SDs as measures of confidence intervals (uncertainties) associated with the method utilized (see Fig. 6; dashed lines). In these calculations, we used daily temperature and salinity profiles at moorings to estimate geostrophic currents and their variability. Over the slope segment between the $\mathrm{M} 1_{1}$ and $\mathrm{M}_{3}$ moorings, the contribution of barotropic flow to the along-slope ACBC velocities is substantially larger when compared with the slope segments between deep moorings. This enhanced contribution is evident, for example, from the larger differences (exceeding 1 SD) between the magnitude of baroclinic currents and measured velocities, reach- ing $\sim 11 \mathrm{~cm} \mathrm{~s}^{-1}$ between the $\mathrm{M}_{2}$ and $\mathrm{M}_{3}$ moorings. At the sites of the shallow-water moorings $\mathrm{M} 1_{1}$ and $\mathrm{M} 1_{2}$ the vertical structure of the geostrophic velocities differs substantially from the vertical structure evident from the 20132015 measured currents (Fig. 6a). The strongest discrepancies were found in the upper and bottom layers, likely suggesting that ageostrophic processes in the boundary layers play a role in maintaining vertical ACBC shape. Moreover, density gradients between moorings, which we used in our calculations of geostrophic currents, were estimated over the distances exceeding the local baroclinic Rossby radius of deformation ( $\sim 7 \mathrm{~km}$; Nurser and Bacon, 2014), which may serve as an additional source of the disagreement between the geostrophic and measured currents because of synoptic-scale variability not resolved by our coarse mooring observations.

The distinct shape and relatively large (up to $10 \mathrm{~cm} \mathrm{~s}^{-1}$; Fig. 6a) difference between the observed velocities and those derived using geostrophic equations at shallow moorings $\mathrm{M} 1_{1}-\mathrm{M} 1_{3}$ suggest that the geostrophic balance in proximity to the density front may be violated.

\subsection{Persistence of current velocities}

The ACBC in the eastern part of the EB is subject to strong temporal variability evident in both current speed and direction (Pnyushkov et al., 2015). Our analysis shows no exception, and strong variability of current directions is evident in the velocity records from the mooring array collected in 2013-2015.

The distributions of current speed and direction at the $\sim 250 \mathrm{~m}$ level (close to the AW temperature core) demonstrate steady along-slope flow at the three shallowest moorings $\left(\mathrm{M} 1_{1}-\mathrm{M} 1_{3} ;\right.$ Fig. 7$)$. At these moorings, we found a relatively good match between the direction of the strongest currents (derived from all sectoral bins) and the directions of 

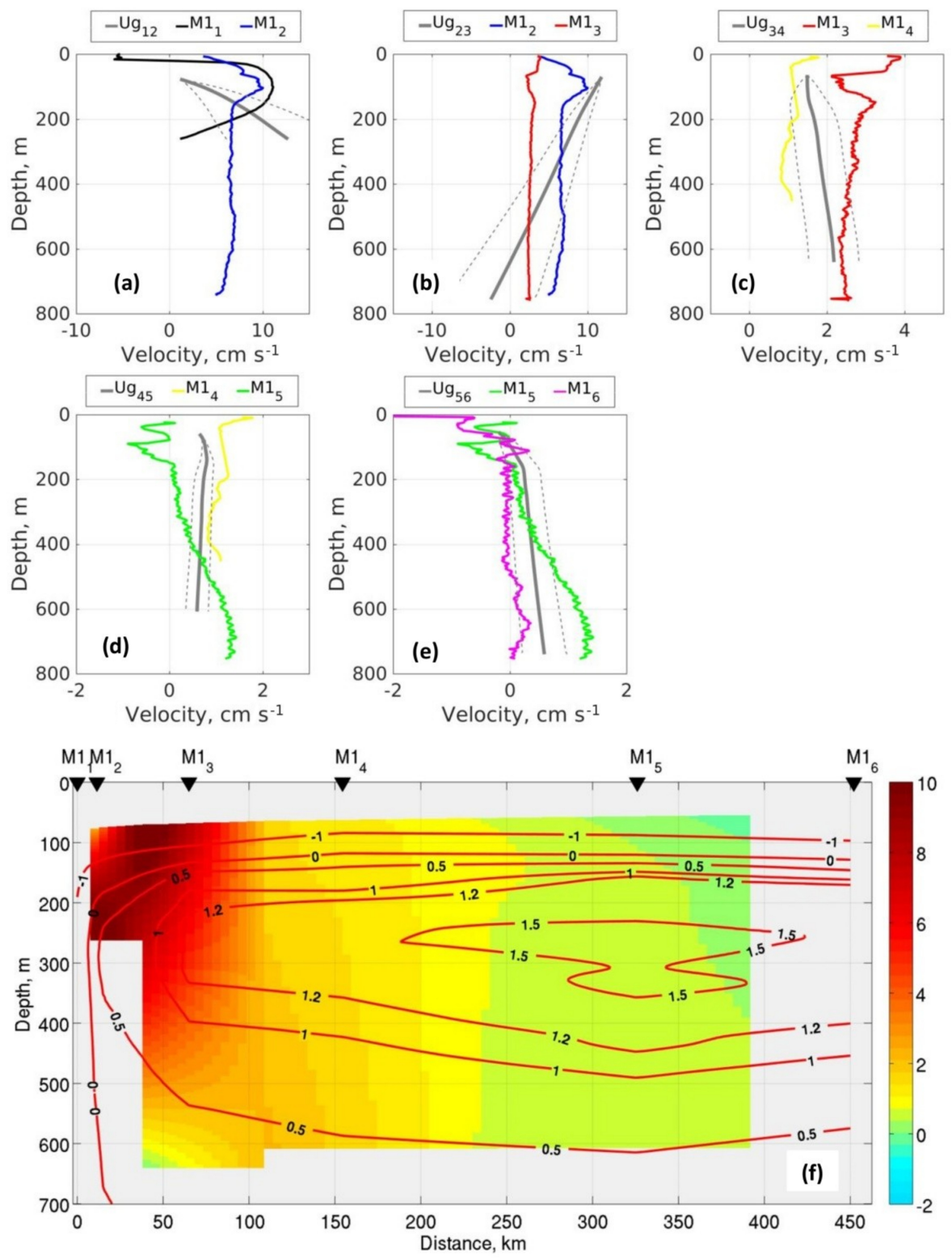

Figure 6. (a)-(e) Vertical profiles of geostrophic velocities ( $U g$; gray lines; dashed lines indicate intervals of 1 standard deviation) for each pair of moorings from the Laptev Sea slope. The 2013-2015 mean eastward velocities at six moorings are shown by color profiles. (f) Crossslope distribution of geostrophic velocities (color, $\mathrm{cm} \mathrm{s}^{-1}$ ) and water temperature along $125^{\circ} \mathrm{E}$ section (isolines, ${ }^{\circ} \mathrm{C}$ ). All geostrophic velocities were calculated using 2013-2015 mean temperature and salinity mooring profiles. Positive velocities are eastward. Black triangles show the mooring positions.

prevailing flow (black arrow; see moorings $\mathrm{M}_{2}$ and $\mathrm{M}_{3}$ ). In contrast, the persistence of current directions at the three deeper moorings was significantly weaker - evident, for example, at $\mathrm{M}_{5}$, where there is essentially no prevailing current direction, and the mean and the strongest sectoral currents differ significantly (Fig. 7). Weak persistence of current direction over the deep part of the Laptev Sea slope is also confirmed by the distribution of SD ellipses (Fig. 5). In contrast to the stretched shapes of these ellipses at the $\mathrm{M}_{1}$ and
$\mathrm{M}_{2}$ moorings, the ellipses at deep moorings have a circular shape, which suggests no prevailing direction of the flow.

Weaker persistence of currents at the three deep moorings $\mathrm{M} 1_{4}-\mathrm{M} 1_{6}$ is likely caused by weaker mean flow and stronger relative contributions from mesoscale variability. For example, observations carried out at the $\mathrm{M}_{4}$ mooring site in 2009-2011 revealed multiple events of strong current rotation, when flow changes its direction by more than $90^{\circ}$ over a short (from 4 to 15 days) period of time (Pnyushkov et al., 2018). These events potentially indicate the passage 

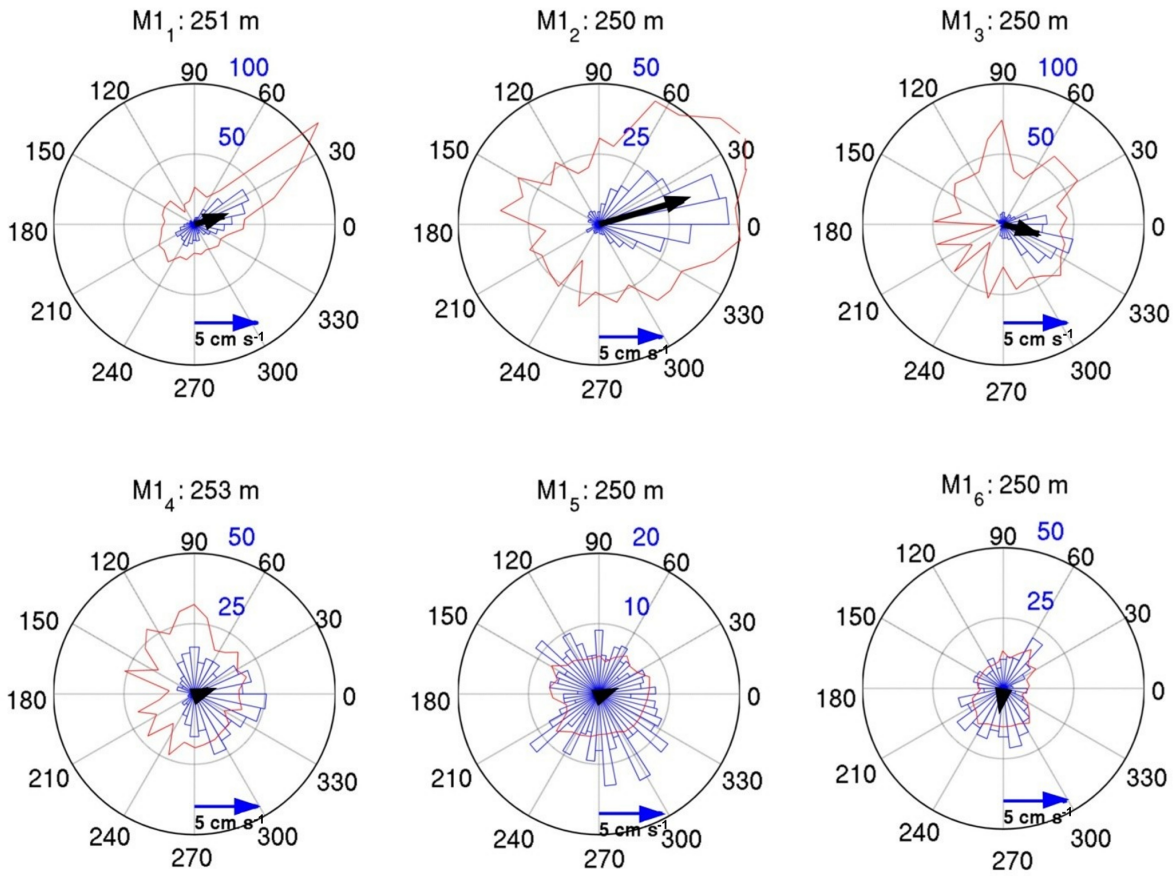

Figure 7. Current directions and speed at $\sim 250 \mathrm{~m}$ (in proximity to AW temperature core) at six moorings at the Laptev Sea slope in 20132015. Blue sectors show the distribution of current directions (persistence of direction is given in days; gray circles). Red lines indicate the mean current speed within $12^{\circ}$ directional bins. The black arrows represent the record-long mean currents. The same linear scale is used to show the mean current speed within directional bins and the mean current vectors.

of eddies through the mooring site. Typical values of the inferred maximum rotation velocity in eddies registered at the $\mathrm{M} 1_{4}$ mooring site in $2009-2011$ are $\sim 5 \mathrm{~cm} \mathrm{~s}^{-1}$, although this value can exceed $15 \mathrm{~cm} \mathrm{~s}^{-1}$, which is comparable, for example, to an eddy-induced current amplification found in the M1 5 mooring record in June-July 2014.

Topographically trapped barotropic Rossby waves can also contribute to current variability. In the Arctic Ocean such waves have been observed both in the Canada Basin (Timmermans et al., 2010) and over the Eurasian slope (e.g., Voinov and Zakharchuk, 1999; Zakharchuk, 2009). However, wavelet analysis of isopycnal displacements estimated using the MMP record at mooring $\mathrm{M}_{3}$ located at the steep segment of the continental slope (not shown) does not show persistent spectral power (consecutive spectral power peaks) at typical periods of topographic Rossby waves (7-60 days; Zakharchuk, 2009) or significant coherence between vertical isopycnal displacement and lateral velocity components. Such waves are therefore not likely to contribute strongly to the current variability found in our area of study.

\section{Estimates of volume, heat, and salt transports across the $125^{\circ} \mathrm{E}$ section}

Observations over the 2-year (2013-2015) period were used to estimate volume, heat, and salt transports in the eastern EB for the eastward (normal to the cross section) direction of the flow.

\subsection{Net volume transports across the $125^{\circ} \mathrm{E}$ section}

Since the depth-integrated volume transport depends on both the current speed and water column height, shallower moorings may have weaker transport despite stronger currents. As an illustration, at the Laptev Sea slope, the largest monthly depth-integrated water transport $\left(55.6 \pm 1.5 \mathrm{~m}^{2} \mathrm{~s}^{-1}\right.$; here, values after plus and minus signs indicate the standard error of the monthly mean) was found at mooring $\mathrm{M}_{2}$ and not at $\mathrm{M} 1_{1}$, which is caused by greater depth at this mooring location (Fig. 8; Table 2). Further north, depth-integrated water transports decrease to $20.1 \pm 0.6 \mathrm{~m}^{2} \mathrm{~s}^{-1}$ at $\mathrm{M}_{4}$ and to $8.4 \pm$ $0.8 \mathrm{~m}^{2} \mathrm{~s}^{-1}$ at $\mathrm{M} 1_{5}$. At $\mathrm{M} 1_{6}$, the record mean along-slope water transport was small and negative $\left(-0.3 \pm 0.3 \mathrm{~m}^{2} \mathrm{~s}^{-1}\right)$, resulting from the small westward component of the prevailing current there (see discussion in Sect. 4.2).

The net volume transport across the Laptev Sea slope was estimated using monthly averaged data and varies widely from $\sim 0.3 \pm 0.8$ to $\sim 9.9 \pm 0.8 \mathrm{~Sv}$ (Fig. $8 \mathrm{~b}$ ). The largest $(\sim 9.9 \pm 0.8 \mathrm{~Sv})$ net transport was observed during JuneJuly 2014 and resulted from stronger depth-integrated transports at two deep moorings $\mathrm{M}_{4}$ and $\mathrm{M} 1_{5}$ (Fig. 8a, green and yellow lines). The mechanisms behind this transport amplification are not completely clear. In part, the strongest net vol- 
Table 2. Depth-integrated water transports (along-slope, $\mathrm{m}^{2} \mathrm{~s}^{-1}$ ) in the 0-780 m layer in 2013-2015 at six moorings at the Laptev Sea slope.

\begin{tabular}{lcccrrr}
\hline Period & $\mathrm{M}_{1}$ & $\mathrm{M}_{2}$ & $\mathrm{M} 1_{3}$ & $\mathrm{M} 1_{4}$ & $\mathrm{M} 1_{5}$ & $\mathrm{M}_{6}$ \\
\hline Sep 2013-Aug 2014 & $15.4 \pm 0.9$ & $52.9 \pm 2.2$ & $19.4 \pm 0.9$ & $15.0 \pm 1.0$ & $5.4 \pm 1.1$ & $-2.9 \pm 0.4$ \\
Sep 2014-Sep 2015 & $22.4 \pm 1.0$ & $58.6 \pm 2.1$ & $20.9 \pm 0.9$ & $1.3 \pm 1.0$ & $3.4 \pm 0.7$ & $2.6 \pm 0.4$ \\
\hline Total (Sep 2013-Sep 2015) & $18.7 \pm 0.7$ & $55.6 \pm 1.5$ & $20.1 \pm 0.6$ & $8.4 \pm 0.8$ & $4.5 \pm 0.7$ & $-0.3 \pm 0.3$ \\
\hline
\end{tabular}
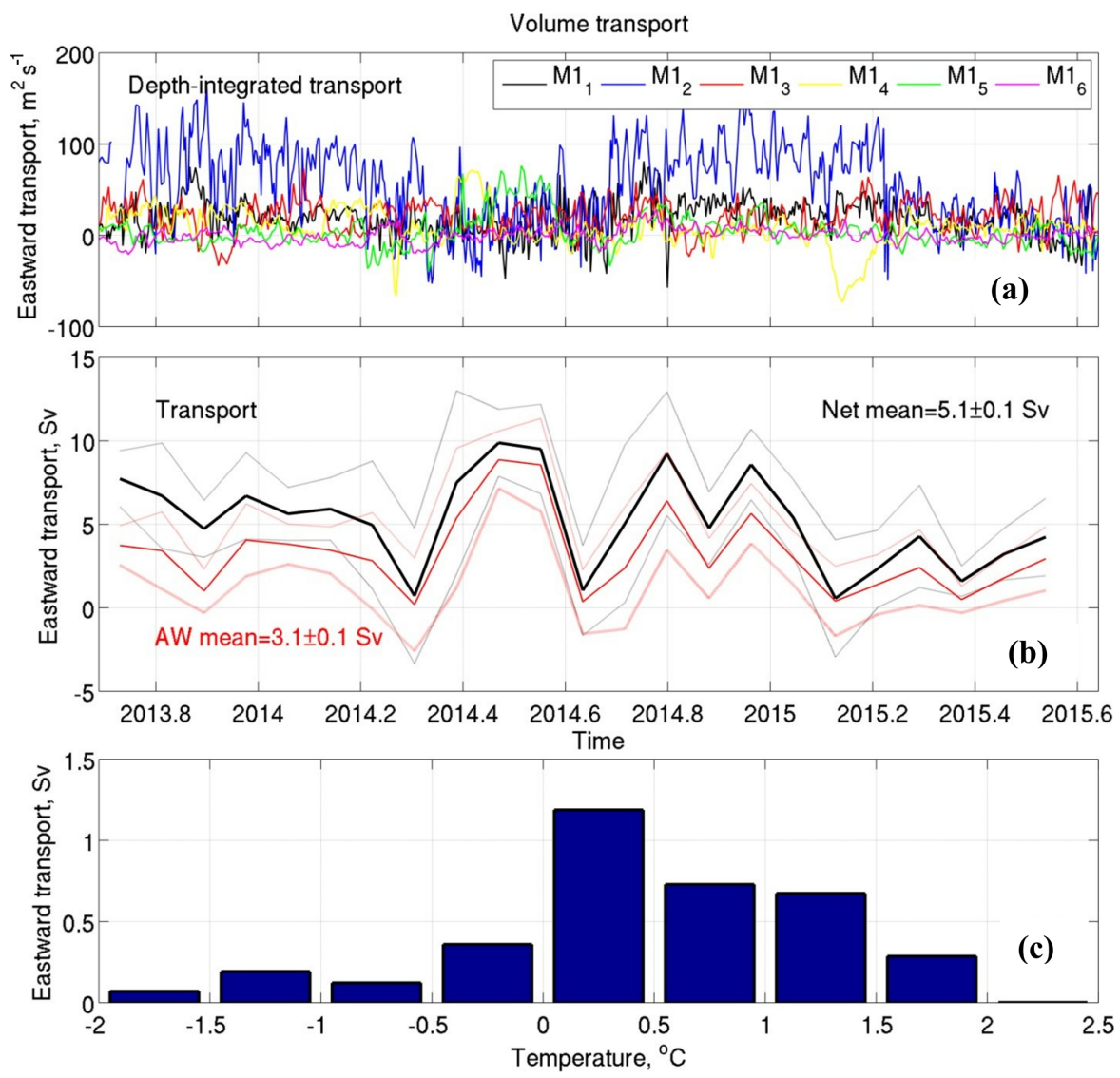

Figure 8. (a) Depth-integrated volume transports $\left(\mathrm{m}^{2} \mathrm{~s}^{-1}\right)$ in the layer spanned by 2013-2015 velocity observations at six moorings at the Laptev Sea slope; (b) monthly net volume transport in the upper $780 \mathrm{~m}$ layer (black) and in the AW layer (red) across the $125^{\circ} \mathrm{E}$ section. Dotted lines show 1 standard deviation intervals. (c) Distribution of eastward volume transports averaged over $0.5^{\circ} \mathrm{C}$ temperature bins.

ume transport in June-July 2014 was caused by a mesoscale eddy, which passed the $\mathrm{M}_{5}$ mooring site and significantly (up to $12 \mathrm{~cm} \mathrm{~s}^{-1}$ ) increased eastward velocities in the entire layer spanned by mooring observations. The velocity increase was not evident at the neighboring moorings $\mathrm{M}_{4}$ and $\mathrm{M}_{6}$ due to the limited size of the eddy (comparable with the local Rossby radius of deformation). The contribution from shallow moorings in this transport enhancement was small, as suggested by a seasonal minimum in the depthaveraged transport at mooring $\mathrm{M}_{2}$ (Fig. 8a, blue line).

The contribution from different parts of the slope to the net volumetric water transport variability was evaluated by estimates of correlations between daily depth-integrated and net volume transports. These statistical estimates suggest that the strongest variability of along-slope transport occurs between the two deep moorings $\mathrm{M}_{4}$ and $\mathrm{M} 1_{5}$, likely due to the largest sectional area between them. For example, the time series for net volumetric transport and depth-averaged transports at moorings $\mathrm{M}_{4}$ and $\mathrm{M} 1_{5}$ are correlated with coefficients of 0.65 and 0.42 (both significant at the $95 \%$ confidence level), respectively. Multivariate linear regression between the daily depth-integrated and net volumetric water transports suggests that the flow variability represented by these two moorings contributes up to $77 \%$ of the net volume transport variability. 
The high-frequency (from 5 to 10 days) variations of depth-integrated transports are attributed to substantial mesoscale variability produced by eddies and ACBC meanders. Because of that, the correlations between daily series of depth-integrated transports at moorings are weak (not exceeding 0.2 ), except for the two closely located moorings $\mathrm{M} 1_{1}$ and $\mathrm{M} 1_{2}$, which are separated by a distance of $\sim 11 \mathrm{~km}$. For these two moorings, the correlation was as high as $0.6 \pm 0.1$. However, the correlation between depthintegrated transports increases if the short-period (mostly incoherent) variability is removed. For example, after averaging over 30-day intervals (the longest period of averaging that enables confident statistics for correlation) the correlation coefficient for two deep moorings $\mathrm{M}_{5}$ and $\mathrm{M} 1_{6}$ (separated by more than $100 \mathrm{~km}$ ) increases from $0.2 \pm 0.1$ to $0.4 \pm 0.1$. This suggests that variability at each mooring includes a substantial high-frequency component that is not resolved by our observations; however, relatively sparsely spaced moorings can successfully capture large-scale dynamics that can be examined once incoherent mesoscale variability is removed.

\subsection{AW transports}

We estimated net volume transports for AW using temperature, salinity, and velocity measurements from the mooring array (Fig. 8c). Volume transport associated with the AW (the transport of waters with $T>0{ }^{\circ} \mathrm{C}$ ) is $\sim 3.1 \pm 0.1 \mathrm{~Sv}$ and contributes $\sim 60 \%$ to net volume transport. The relative contribution from AW transport is $\sim 20 \%$ smaller than expected from the percentage of the area spanned by this water at the $125^{\circ} \mathrm{E}$ section. This difference is mostly due to the decrease in mean eastward velocities with depth (except the $\mathrm{M1}_{6}$ mooring) so that in the AW layer velocities become smaller than those observed in the cold halocline and surface mixed layers. This weakening is evident, for example, at moorings $\mathrm{M}_{2}$ and $\mathrm{M}_{3}$ (Fig. 4, lower panel). For the $\mathrm{M1}_{6}$ mooring at which larger eastward velocities were found in the deep layer (Fig. 4a), another factor at play is seasonal changes in the lower AW boundary. In 2013-2015 this boundary (identified using the position of a $0^{\circ} \mathrm{C}$ isotherm) may shoal to $716 \mathrm{~m}$ so that the AW transport does not include the eastward transport in the layer below this depth. Additionally, there is substantial variability in the AW flow that includes periods of weak or even westward flow. For example, at mooring $\mathrm{M1}_{4}$, depth-integrated volume transport in January 2015 was negative, indicating westward transport during this period.

AW transport at the Laptev Sea slope is highly correlated with net water transport in the upper $780 \mathrm{~m}$ with a correlation of $0.9 \pm 0.1$ (significant at the $95 \%$ confidence level). As a result, the cross-slope pattern of the depth-integrated transports of the AW replicates the pattern of depth-integrated volume transport in the upper $780 \mathrm{~m}$ layer shown in Fig. 8a. For example, the strongest depth-integrated AW transport was found at mooring $\mathrm{M1}_{2}$, the shallowest mooring retaining a
Table 3. Net heat, salt, and volume transports across the $125^{\circ} \mathrm{E}$ section in the upper $780 \mathrm{~m}$ layer in 2013-2015.

\begin{tabular}{lccc}
\hline Period & $\begin{array}{c}\text { Volume } \\
\text { transport, } \\
\text { Sv }\end{array}$ & $\begin{array}{c}\text { Heat } \\
\text { transport, } \\
\text { TW }\end{array}$ & $\begin{array}{c}\text { Salt } \\
\text { transport, } \\
\times 10^{6} \mathrm{~kg} \mathrm{~s}^{-1}\end{array}$ \\
\hline Sep 2013-Aug 2014 & $5.8 \pm 0.2$ & $55.3 \pm 2.8$ & $195 \pm 8$ \\
Sep 2014-Sep 2015 & $4.4 \pm 0.2$ & $38.8 \pm 2.1$ & $147 \pm 7$ \\
\hline Total (Sep 2013-Sep 2015) & $5.1 \pm 0.1$ & $46.0 \pm 1.7$ & $172 \pm 6$ \\
\hline
\end{tabular}

year-round presence of the AW. In January-February 2014, this transport exceeded $150 \mathrm{~m}^{2} \mathrm{~s}^{-1}$ and decreased to almost zero during the summer months (not shown). Depthintegrated AW transports at deep moorings $\mathrm{M}_{3}-\mathrm{M} 1_{5}$ are smaller and do not exceed $70 \mathrm{~m}^{2} \mathrm{~s}^{-1}$ due to a gradual decrease in the eastward component of the boundary current over the slope.

We further note that the largest volume transport ( $1.2 \mathrm{~Sv}$; Fig. 8c) was found at the $0-0.5^{\circ} \mathrm{C}$ temperature range at the boundary between the Fram Strait AW and the Barents Sea AW. This suggests that estimates of AW transports are sensitive to the choice of temperature limits for this water. For example, a change in the temperature limit for the $\mathrm{AW}$ to $0.2{ }^{\circ} \mathrm{C}$ leads to a corresponding $\mathrm{AW}$ volume transport decrease of $0.5 \mathrm{~Sv}$, constituting $\sim 16 \%$ of the mean AW volume transport (Table 3). However, for the accurate separation of AW branches at the Laptev Sea slope, more sophisticated analysis is required.

\subsection{Salt and heat transports across the $125^{\circ} \mathrm{E}$ section}

Estimated heat and salt transports across the $125^{\circ} \mathrm{E}$ section in the upper $780 \mathrm{~m}$ are shown in Figs. 9 and 10. These estimates use along-slope (eastward) velocity components. The 2013-2015 salt transport in the upper $780 \mathrm{~m}$ layer is estimated as $172 \pm 6 \mathrm{Mkg} \mathrm{s}^{-1}$. In the AW layer, salt transport is $112 \pm 4 \mathrm{Mkg} \mathrm{s}^{-1}$, constituting $\sim 65 \%$ of the net salt transport. The use of a higher value of $S_{\text {ref }}$ increases the relative contribution of the AW layer to the net salt transport. For example, for $S_{\text {ref }}=31.7$ (the minimum salinity measured at moorings) we found that this contribution increases to $82 \%$. The major statistics for these transports are summarized in Tables 3 and 4. The 2013-2014 heat transport carried by the AW was $32.7 \pm 1.3 \mathrm{TW}$, constituting $\sim 71 \%$ of the net heat transport in the entire layer spanned by mooring instruments $(46.0 \pm 1.7 \mathrm{TW})$, which is $\sim 11 \%$ higher than the relative contribution from AW to the net volume transport. This high percentage suggests that a substantial portion of heat and salt in the eastern EB is carried by the AW. In the AW layer, heat transport density is larger than in the entire layer spanned by 2013-2015 observations (Fig. 9c). The 2-year mean heat transport density for the AW was $6.8 \pm 0.3 \mathrm{TW} \mathrm{Sv}^{-1}$, which is $\sim 26 \%$ larger than for the net heat transport density of 
Table 4. Atlantic Water heat, salt, and volume transports across the $125^{\circ}$ E section in 2013-2015.

\begin{tabular}{lccr}
\hline Period & $\begin{array}{c}\text { Volume } \\
\text { transport, } \\
\text { Sv }\end{array}$ & $\begin{array}{c}\text { Heat } \\
\text { transport, } \\
\text { TW }\end{array}$ & $\begin{array}{r}\text { Salt } \\
\text { transport, } \\
\times 10^{6} \mathrm{~kg} \mathrm{~s}^{-1}\end{array}$ \\
\hline Sep 2013-Aug 2014 & $3.7 \pm 0.2$ & $38.6 \pm 2.0$ & $131 \pm 7$ \\
Sep 2014-Sep 2015 & $2.6 \pm 0.1$ & $26.4 \pm 1.6$ & $92 \pm 5$ \\
\hline Total (Sep 2013-Sep 2015) & $3.1 \pm 0.1$ & $32.7 \pm 1.3$ & $112 \pm 4$ \\
\hline
\end{tabular}
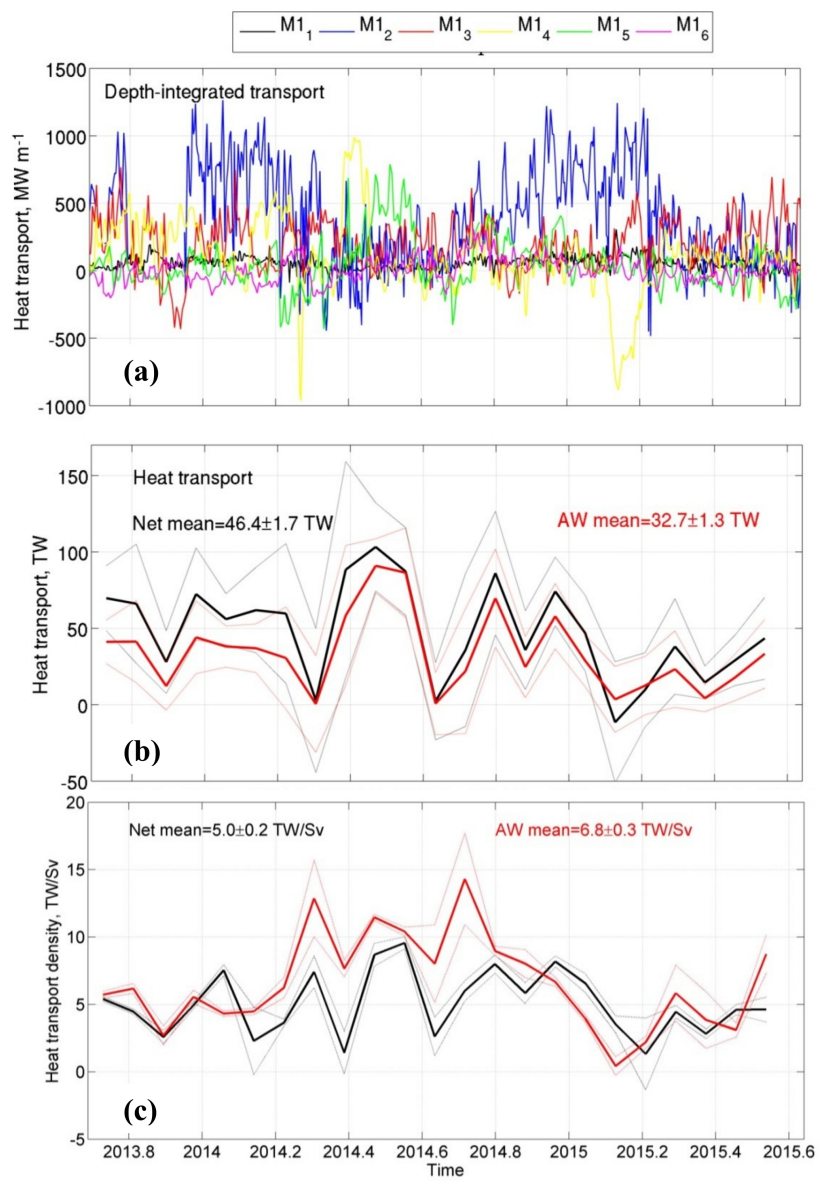

Figure 9. (a) Depth-integrated heat transports in the layer spanned by 2013-2015 CTD and velocity observations at six moorings at the Laptev Sea slope; (b) monthly net heat transport in the upper $780 \mathrm{~m}$ layer (black) and in the AW layer (red) across the $125^{\circ} \mathrm{E}$ section. (c) Monthly density of heat transport across the Laptev Sea slope in the upper $780 \mathrm{~m}$ layer (black curve) and in the AW layer (red curve). Dotted lines show 1 standard deviation intervals.

$5.0 \pm 0.2 \mathrm{TW} \mathrm{Sv}^{-1}$, which also includes fresh and cold waters of the SML and CHL.

The time series of net salt and heat transports in the AW layer are highly correlated with AW volume transports ( $R>0.9$, significant at the $95 \%$ confidence level). Similarly high correlations were also found for the series of depthintegrated heat and salt transports at all moorings. Since the
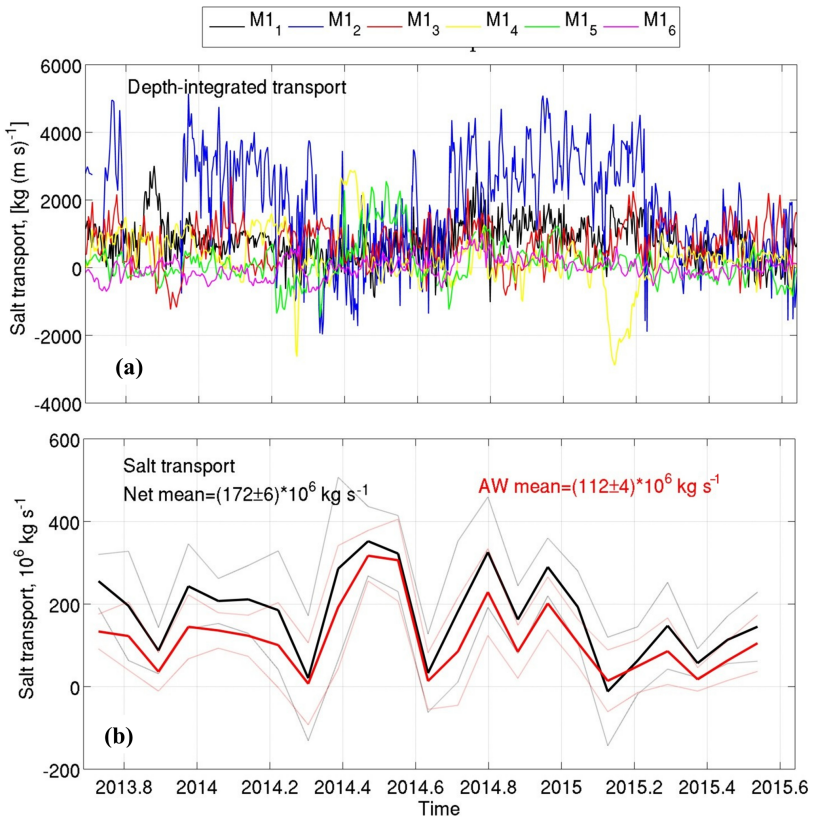

Figure 10. (a) Depth-integrated salt transports in the layer spanned by 2013-2015 CTD and velocity observations at six moorings at the Laptev Sea slope; (b) monthly net salt transport in the upper $780 \mathrm{~m}$ layer (black) and in the Fram Strait AW layer (red) across the $125^{\circ} \mathrm{E}$ section. Dotted lines show 1 standard deviation intervals.

heat and salt transports are influenced by two major factors the speed of currents and temperature-salinity anomalies (the AW layer thickness changes by $5 \%$ only and has a minor role in changes in the AW property transports) - these high correlations suggest that the variability of currents plays the most significant role in governing heat and salt transports changes in this part of the EB. Based on the correlations between transports, we conclude that the currents are responsible for $\sim 90 \%$ of the variability of heat and salt transports at the scales resolved by our records (in this estimate we used variance as a qualitative measure of variability). The remaining $\sim 10 \%$ is controlled by temperature and salinity anomalies together with the temporal variability of the AW layer thickness. The level of correlation between the volume and heat transports is high for the current choice of $T_{\text {ref }}$, but remains high for alternate choices (e.g., $R>0.8$ for $T_{\text {ref }}=0^{\circ} \mathrm{C}$ ). The multivariate linear regression between daily depth-integrated heat transports and mean temperatures-salinities within the AW layer used as the predictors and $F_{\mathrm{H}}$ suggests approximately the same $(>90 \%)$ contribution from currents (estimated as the sum of the derived coefficients of determination for $D_{\mathrm{W}}$ ) to the net heat transport.

Summarizing, we conclude that AW contributes substantially (from $60 \%$ to $71 \%$ ) to the net water, heat, and salt transports along the Laptev Sea slope in the upper $780 \mathrm{~m}$. However, the estimates of heat and salt transports and their relative contributions are subject to uncertainties related to 
the unclosed mass balance. Spatiotemporal variability, which is not resolved by available mooring records, adds uncertainty to our estimates of transports.

\subsection{Temporal variability of transports}

\subsubsection{Year-to-year changes}

In 2013-2015 the net volume, heat, and salt transports across the Laptev Sea slope experienced strong temporal changes. During this period, the net volume transport decreased from $5.8 \pm 0.2 \mathrm{~Sv}$ in $2013-2014$ to $4.4 \pm 0.2 \mathrm{~Sv}$ in $2014-2015$, and the AW volume transport was reduced correspondingly from $3.7 \pm 0.2$ to $2.6 \pm 0.1 \mathrm{~Sv}$ (Table 3 ). Because of the limited length of the available records, these estimates may not be representative of transports across longer timescales. Declines were also found in the net and AW heat transports (Fig. 9b), likely replicating the decreased water transports across the Laptev Sea slope. To provide more robust estimates of year-to-year changes in heat transports in the case of decreased and (in addition) highly variable water transports, we have computed time series of heat transport density. Since both the heat transport and heat transport density quantify heat fluxes, their time series are highly correlated (the coefficients of linear correlation are $0.8 \pm 0.1$ and $0.7 \pm 0.1$ for the heat transport density for the upper $780 \mathrm{~m}$ and in the AW layer, respectively). Taking into account that the heat transport density is normalized using the volume transport, this high correlation suggests that the temperature regime in the AW layer, including heat fluxes, is strongly coherent with the volume of AW advected through the Laptev Sea slope. Following the heat transport, the heat transport density demonstrates a slight decrease from $7.8 \pm 0.4 \mathrm{TW} \mathrm{Sv}^{-1}$ in $2013-$ 2014 to $6.3 \pm 0.4 \mathrm{TW} \mathrm{Sv}^{-1}$ in $2014-2015$, though the estimated decrease rate is statistically insignificant (using the Student's $t$ test), making our conclusion about the decline of heat transport across the Laptev Sea slope more speculative (Fig. 9c).

In order to better assess year-to-year transport changes, all depth-integrated and volumetric transports were estimated individually for the first (September 2013-August 2014) and second (September 2014-September 2015) years. Comparison of annual mean estimates for depth-integrated and net transports of volume, heat, and salt at moorings confirms the substantial variability of these transports. For example, at mooring $\mathrm{M1}_{4}$, where the strongest year-to-year changes in the depth-integrated volume transport occurred, this transport decreases by an order of magnitude from $15.0 \pm 1.0$ in 2013-2014 to $1.3 \pm 1.0 \mathrm{~m}^{2} \mathrm{~s}^{-1}$ in 2014-2015, resulting in a corresponding decrease in net volume transport (Tables 2 and 3). This strong decrease was due to the change to the northwest of the predominant direction of the flow evident at the $\mathrm{M}_{4}$ mooring site in February-March 2015, alongside the substantial (up to $15 \mathrm{~cm} \mathrm{~s}^{-1}$ ) enhancement of the daily current speed within the $180-400 \mathrm{~m}$ layer. In this period, the flow demonstrated pronounced baroclinic vertical structure (not shown), in which the largest velocities were found at the $\sim 450 \mathrm{~m}$ level (at the last level with velocity observations). These changes in the volume transport resulted in the decrease of heat and salt transports. For instance, net heat (salt) transports decreased from $55.3 \pm 2.8 \mathrm{TW}\left(195 \pm 8 \mathrm{Mkg} \mathrm{s}^{-1}\right)$ in 2013-2014 to $38.8 \pm 2.1 \mathrm{TW}\left(147 \pm 7 \mathrm{Mkg} \mathrm{s}^{-1}\right)$ in 20142015.

\subsubsection{Seasonal and monthly variability}

In addition to significant year-to-year changes, volume transports demonstrated substantial seasonal variations. We determined these changes by applying Morlet wavelet power spectra to depth-integrated AW transports at moorings (Fig. 11; Grinsted et al., 2004). The focus on the AW layer was due to the seasonal mode of variability being dominant in this layer at the continental slope of the eastern EB in 2008-2011; the seasonal mode described up to $70 \%$ of the variability in the AW temperatures and ACBC velocities (Pnyushkov et al., 2015).

However, 2013-2015 mooring records show a clear seasonal signal indicated as a maximum in the wavelet power spectra with periods from 10 to 12 months in the depthintegrated AW transport only at the two shallow moorings $\mathrm{M}_{2}$ and $\mathrm{M} 1_{3}$ (Fig. 11). The relative contribution of seasonal changes to depth-integrated transport variability varies from $\sim 30 \%$ at the $\mathrm{M}_{2}$ mooring site to $\sim 11 \%$ at the $\mathrm{M} 1_{4}$ mooring (estimated from the ratio of wavelet power at the seasonal scales to the total wavelet power; Fig. 11). The seasonality in $\mathrm{AW}$ transport at the $\mathrm{M}_{2}$ and $\mathrm{M}_{3}$ moorings may be connected to significant seasonality in temperatures and velocities also observed over the upper slope northeast of Svalbard, with maximum values in late fall to early winter (Renner et al., 2018).

Substantial power for all mooring records is evident in the wavelet spectra of the AW transports with periods from $\sim 30$ to $\sim 250$ days (Fig. 12). Note that strong variability at the same scales was also found in current speed records at NABOS mooring M4 in 2004-2005 located at the northeast slope of Svalbard ( $\sim 30^{\circ} \mathrm{E}$; unpublished results) and at A-TWAIN (long-term variability and trends in the Atlantic Water inflow region) moorings in 2012-2013 (Renner et al., 2018). Moreover, strong variability at scales from one to several months was found in wavelet power of baroclinic velocities calculated using temperature and salinity from the two deep moorings $\mathrm{M}_{4}$ and $\mathrm{M}_{5}$ (Fig. 12). These moorings were chosen because they provide the highest correlations with the net AW transport across the Laptev Sea slope and thus describe the dominant part of AW transport variability. Both wavelet power spectra have similarities at timescales from 50 to 100 days, with similar statistically significant peaks of wavelet power for both baroclinic currents and AW transports in 2013-2014 and, to a lesser extent, in 2014-2015 (Fig. 12). This suggests that the variability of the cross-slope 

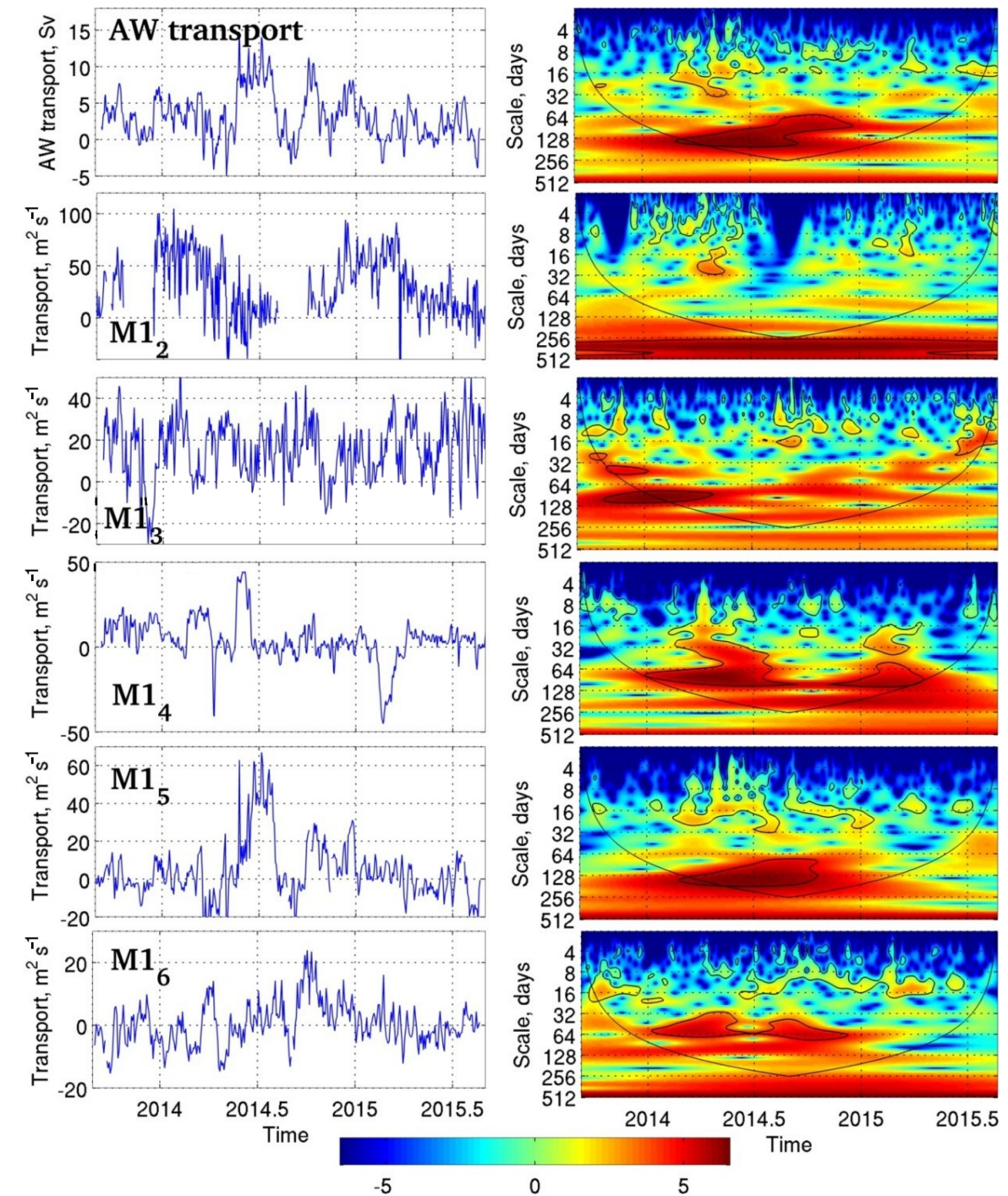

Figure 11. Depth-integrated AW transports at moorings, volume transport in the AW layer at the Laptev Sea slope, and their wavelet powers (in units of normalized variance). Scales indicate periods defined in wavelet spectral analysis. Black lines show significance at the $95 \%$ confidence level. Outside the cone of influence (black lines), the edge effect from finite series length becomes important.

density gradients is coherent with the variability of transports at these scales in this part of the EB. We have not found any statistical relationship between the AW depth-integrated transports and the atmospheric forcing. For example, correlations between the ERA-Interim (Simmons et al., 2006) daily wind velocities and wind vorticity with ocean transports for all moorings were low $(R<0.2)$ and were accompanied by different wavelet patterns (not shown).

\subsubsection{Concluding remarks on transports}

New observations have been used to demonstrate that water, heat, and salt transports across the Laptev Sea slope exhibited strong changes in 2013-2015 - as evident, for example, from the strong year-to-year changes in net volume transport (Fig. 8). These changes were most pronounced at deep moorings, where the year-to-year difference in depth-integrated transports can be as large as the record-long means. The yearto-year changes in volume transports were accompanied by substantial monthly changes also evident in cross-slope baroclinic geostrophic velocities, suggesting that density-driven currents are the likely contributor to the variability of transports at monthly temporal scales in this part of the EB. 

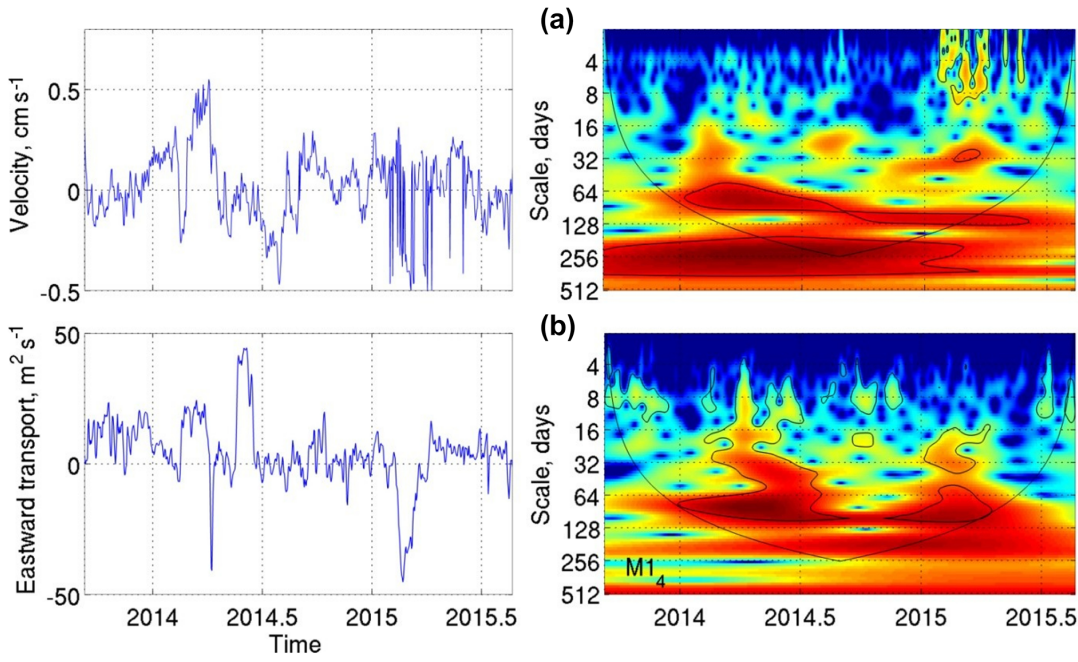

(b)

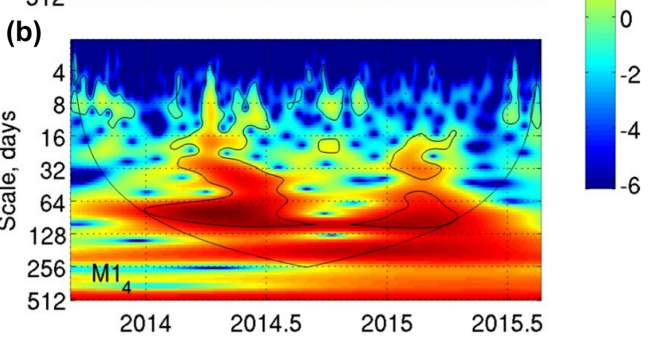

Figure 12. (a) Depth-averaged baroclinic velocities $\left(\mathrm{cm} \mathrm{s}^{-1}\right)$ in the AW layer (positive is eastward) between moorings $\mathrm{M} 1_{4}$ and $\mathrm{M} 1_{5}$, estimated using geostrophic calculations, and their wavelet power. Before averaging, all baroclinic velocities profiles were shifted to satisfy a zero velocity condition at the surface. Time series and wavelet power (b) of depth-integrated transport in the AW layer at mooring M14. All wavelet powers are in units of normalized variance. Black lines show significance at $95 \%$ confidence level peaks.

\section{Discussion and conclusions}

\subsection{Along-slope transports}

Mooring observations suggest that in the upper $780 \mathrm{~m}$ layer, the ACBC advects $\sim 5.1 \pm 0.1 \mathrm{~Sv}$ of water, predominantly in the eastward direction, and $\sim 3.1 \pm 0.1 \mathrm{~Sv}$ ( or $\sim 70 \%$ ) of this volumetric transport is associated with $\mathrm{AW}\left(T>0.0^{\circ} \mathrm{C}\right)$ - the dominant water mass at the Laptev Sea slope. The direction of 2013-2015 mean water transport agrees well with local topography. Up to $70 \%$ of the net volume transport in the eastern EB in the upper $780 \mathrm{~m}$ layer is carried by the AW.

These estimates of the net volume transport at the Laptev Sea slope agree relatively well (within the range of uncertainties for the means) with the $5 \pm 1 \mathrm{~Sv}$ of advective transport at the junction of Lomonosov Ridge and the Siberian shelves estimated by Woodgate et al. (2001) in the upper $\sim 1200 \mathrm{~m}$ layer for $1995-1996$. This estimate is only $0.1 \mathrm{~Sv}$ smaller than our estimate for the 2013-2015 net water transport across the $125^{\circ} \mathrm{E}$ section. Approximately the same volume transport over a $\sim 30 \%$ broader depth range at the Lomonosov Ridge suggests that the flow in recent years was enhanced when compared with the mid-1990s. The same difference $(\sim 0.1 \mathrm{~Sv})$ was found between the AW transport at the Laptev Sea slope and that reported in Fram Strait, where mooring-based observations collected in 1997-2010 suggest a mean northward (into the Arctic Ocean) transport of AW (waters warmer than $2^{\circ} \mathrm{C}$ ) of $3.0 \pm 0.2 \mathrm{~Sv}$ (BeszczynskaMöller et al., 2012).

A comparison of the 2013-2015 mean AW transport at the Laptev Sea slope with estimates available for the northeast slope of Svalbard suggests large (but within the $1 \mathrm{SD}$ range) differences in these transports. According to Vage et al. (2016), the snapshot AW transport in the area to the north of Svalbard was $1.6 \pm 0.3 \mathrm{~Sv}$ in September 2012, differing by $\sim 1.5 \mathrm{~Sv}(\sim 50 \%)$ from our record mean AW transport across the $125^{\circ} \mathrm{E}$ section, but well within the range of synoptic-scale spikes in our record (Fig. 8). A smaller difference $(\sim 0.8 \mathrm{~Sv})$ was found for the estimate reported by Pérez-Hernández et al. (2017), who reported along-slope AW transport of $2.31 \pm 0.29 \mathrm{~Sv}$ based on synoptic-scale crossslope CTD sections between 21 and $33^{\circ} \mathrm{E}$. The plausible reason for those differences is different timescales of observations used for transport estimates (i.e., synoptic scale at Svalbard and annual scale at the Laptev Sea slopes). Moreover, a seasonality of ocean currents to the north of Svalbard with amplified AW current speed in winter suggests that the annual AW transport is higher when compared with the reported fall estimates (Randelhoff et al., 2015; Renner et al., 2018). In addition, all reported AW transports estimated in proximity to Svalbard were based on geostrophic calculations and may thus underestimate the barotropic component of the flow, from which contributions to the net water transport may be significant.

The mean heat transport carried by AW along the Laptev Sea slope was quantified as high as $32.7 \pm 1.3 \mathrm{TW}$. At the Laptev Sea slope, AW heat transport constitutes $\sim 71 \%$ of the net heat transport $(46.0 \pm 1.7 \mathrm{TW})$, confirming a dominant role for AW heat in the thermal balance of the intermediate ocean layer in the EB. Moreover, since velocity and CTD observations used for calculating heat transports at moorings do not always cover the entire layer spanned by the AW (see Sect. 2 for details), the actual AW heat transport may be even higher. 
Estimates of transports using sparsely spaced moorings may suffer from cross-slope ACBC meandering. In order to estimate the potential impact of meandering on volume transports, we used simulations performed with a state-ofthe-art ECCO (Estimation of the Circulation and Climate of the Ocean) numerical model (Nguyen et al., 2017). This global model has a $4 \mathrm{~km}$ spatial resolution, which is capable of capturing possible cross-slope migration of the ACBC velocity core. The model was successful in demonstrating a synergy between observations carried out from drifting platforms in the Arctic Ocean and coupled ocean-sea ice modeling, as well as improving the circulation pattern in regions with sparse data coverage, such as the eastern Arctic and the seasonal ice zones (for details, see Nguyen et al., 2017). For the eastern EB, the model reproduces a velocity pattern with two cores; the deep velocity core was over 1200-1700 m bottom depths at the slope segment between the $\mathrm{M}_{2}$ and $\mathrm{M}_{3}$ moorings, and the shallow velocity core was simulated over $350-400 \mathrm{~m}$ bottom depths. The simulated ACBC meandering at the Laptev Sea slope is estimated by calculating the SD of the position of the deep ACBC velocity core. We found that the estimated standard deviation is small, less than $8 \mathrm{~km}$. We also compared 2004-2015 simulated mean volume transports estimated within the upper $\sim 800$ m layer using all model grid points along the mooring section with those made using a few grid points corresponding to the sites of NABOS moorings only. This comparison showed a $6 \%$ difference, which suggests that transport unresolved by moorings due to cross-slope meandering of the velocity core is small.

\subsection{Potential mechanisms of transport variability}

The complex nature of the ACBC leads to a diversity of hypotheses for the physical mechanisms that control the transports in the eastern EB. For example, at longer (interannual) timescales, the variability may be dominated by barotropic forces (e.g., advection of potential vorticity with the Barents Sea branch of the AW) as suggested by good agreement between the mean current in the upper $780 \mathrm{~m}$ layer and local topography, a feature of the barotropic boundary current aligned to the continental slope (Fig. 5). AW transport during 2013-2015 at the Laptev Sea slope agrees well with that reported for Fram Strait moorings (Schauer et al., 2004, 2008; Beszczynska-Möller et al., 2012), likely suggesting a causal linkage between water transports at both sites at annual scales. However, due to the limited length of mooring records at the Laptev Sea section, we cannot quantify this relationship statistically.

At shorter (monthly to seasonal) timescales, variability is likely linked to changes in water density gradients, as suggested by the similarity of the wavelet power spectra of geostrophic velocities and depth-averaged AW transports at timescales from 50 to 100 days (Fig. 12).

Atmospheric circulation is also an important factor driving oceanic circulation at various scales. For example, Nøst and
Isachsen (2003) suggested the influence of wind curl in the Nordic Sea on the ACBC circulation in the Arctic Ocean. For the eastern EB, wind pattern has an important or even dominant influence on the circulation and freshwater redistribution in the upper layer (Morison et al., 2012). However, we did not find a statistical relationship between ACBC transports along the Laptev Sea slope and local winds. A weak relationship between local winds and currents at the Laptev Sea slope was also reported earlier for the central Laptev Sea slope $\left(\sim 125^{\circ} \mathrm{E}\right)$ by Pnyushkov et al. (2015), who noted weakly correlated winds and ACBC velocities within the AW layer and in the halocline. However, the atmospheric impact on volume transports may be nonlocal. For instance, based on a year-long current record in the St. Anna Trough, Kirillov et al. (2012) suggested that the changes in atmospheric circulation regime in the northern parts of the Barents and Kara seas influence the intensity of Barents Sea AW exchange with the deep EB, likely impacting along-slope transports at the Laptev Sea slope.

To quantify nonlocal wind impact, we calculated lagged correlations (with a maximal lag of 36 months - this time is presumably enough to advect the signal from Fram Strait to the Laptev Sea slope) between weekly ERA-Interim winds (zonal and meridional wind components and wind speed) and the net volume transports at the Laptev Sea slope. The wind components were taken for all available reanalysis nodes located in the EB from Fram Strait to the central Laptev Sea. The highest correlations with the wind at the sites of reanalysis nodes were low ( $R=0.27 \pm 0.15)$, but statistically significant, with a spotty spatial pattern of the time lags at which those correlations were found. These low correlations likely suggest that the nonlocal atmospheric impact on property transports in the eastern EB cannot be identified robustly at temporal scales resolved by our relatively short (2-year-long) records.

\subsection{Limitations of the analysis}

Estimates for the heat, salt, and volume transports reported in this study are subject to some caveats. For example, the sparse spacing between moorings, which varies from 10 to more than $100 \mathrm{~km}$, does not allow for the interpretation of some mesoscale features, such as the eddies and meanders found in single mooring records and depth-averaged transports. Their accurate description requires knowledge of the horizontal pattern of ACBC flow; thus, higher spatial resolution would provide more accurate transport estimates (Våge et al., 2016; Pérez-Hernández et al., 2017). The mesoscale variability evident in our mooring records masks the lowfrequency signal, reducing coherence between daily depthaveraged transports; however, this coherence increases when monthly averaging is applied.

The estimates of AW transports are also sensitive to the temperature and salinity ranges used for the identification of this water. At the central Laptev Sea slope, AW comprises 
water from the Fram Strait and Barents Sea AW branches and the product of their mixing. However, we still do not have reliable criteria for separating waters of these two branches, taking into account their complex transformations and interactions on the way from upstream locations to the Laptev Sea. At the same time, a good match between volume transports at the central Laptev Sea slope (3.1 Sv) and in Fram Strait $(\sim 3.0 \mathrm{~Sv})$ indicates that the selected definition of AW $\left(T>0{ }^{\circ} \mathrm{C}\right)$ is reasonable.

The limited length of 2013-2015 NABOS mooring records restricts our ability to understand the important features of transport variability at temporal scales not resolved by the records. An evident decrease in transports in 20142015 in comparison with 2013-2014 is robust, but cannot be considered representative for longer timescales. Estimates of substantial year-to-year changes in net and AW transports across the slope in the eastern EB are also trustworthy and agree well with dominant variability at the same scales reported for Fram Strait transports (Schauer et al., 2008).

\subsection{Concluding remarks}

Despite the limitations for analysis, we argue that our study is an important step toward a better understanding of the dynamics of the Arctic Ocean, as it provides the first observational estimates for heat, salt, and volume transports along the Laptev Sea slope. All these transports represent vitally important information for the validation of state-of-the-art numerical models.

The 2 years of mooring observations suggest that the AW dominates in the ACBC heat, salt, and water transports over the Laptev Sea slope; these transports are likely controlled by a host of factors acting at different timescales. We found that the low-frequency (year-to-year) changes are the most pronounced modes of variability for the transports at the Laptev Sea slope in recent years - the time when significant changes in the thermohaline state and circulation occur in the eastern EB (e.g., Polyakov et al., 2013; 2017; Pnyushkov et al., 2015). An increased role for Atlantic inflows in those changes suggests that the eastern EB is now in a transition to a new thermohaline state similar to that in the western part of the EB and in the Nordic Seas (see Polyakov et al., 2017, for discussion). However, the substantial year-to-year changes in AW transports found at the slope of the Laptev Sea in 2013-2015 likely suggest that robustly documenting the longer-term tendencies of these transitions requires further observations.

Data availability. All mooring data described in this paper can be accessed from the National Science Foundation Arctic Data Center (https://arcticdata.io/catalog/\#view/arctic-data.7792. 4/, Polyakov, 2016).
Supplement. The supplement related to this article is available online at: https://doi.org/10.5194/os-14-1349-2018-supplement.

Author contributions. AVP carried out the calculations and statistical analysis of transports. All authors contributed to the analysis and interpretation of the results and writing the paper.

Competing interests. The authors declare that they have no conflict of interest.

Acknowledgements. The authors thank the editor, Maria Luneva, and Benjamin Rabe for assistance in evaluating this paper. This study was supported by NSF grant 1708427 (A. Pnyushkov, I. Polyakov). The mooring- and ship-based oceanographic observations in the eastern EB were conducted within the framework of the NABOS project, with support from the NSF (grants AON-1203473, AON-1338948, and AON-1203146). V. Ivanov acknowledges funding from the Ministry of Education and Science of the Russian Federation (project RFMEFI61617X0076). G. Alekseev was supported by RFBR grant 18-05-60107. A. Sundfjord was supported by the Fram Centre "Arctic Ocean" A-TWAIN project.

Edited by: A. J. George Nurser

Reviewed by: Benjamin Rabe and Maria Luneva

\section{References}

Aagaard, K. and Greisman, P.: Toward new mass and heat budgets for the Arctic Ocean, J. Geophys. Res., 80, 3821-3827, 1975.

Aagaard, K., Coachman, L. K., and Carmack, E. C.: On the halocline of the Arctic Ocean, Deep-Sea Res., 28, 529-545, 1981.

Aksenov, Y., Ivanov, V. V., Nurser, A. J. G., Bacon, S., Polyakov, I. V., Coward, A. C., Naveira-Garabato, A. C., and Beszczynska-Moeller, A.: The Arctic Circumpolar Boundary Current, J. Geophys. Res., 116, C09017, https://doi.org/10.1029/2010JC006637, 2011.

Alkire, M. B., Polyakov, I., Rember, R., Pnyushkov, A., Ivanov, V., and Ashik, I.: Combining physical and geochemical methods to investigate lower halocline water formation and modification along the Siberian continental slope, Ocean Sci., 13, 983-995, https://doi.org/10.5194/os-13-983-2017, 2017.

Bauch, D., Dmitrenko, I. A., Kirillov, S. A., Wegner, C., Hölemann, J., Pivovarov, S., Timokhov, L. A., and Kassens, H.: Eurasian Arctic shelf hydrography: Exchange and residence time of southern Laptev Sea waters, Cont. Shelf Res., 29, 1815-1820, https://doi.org/10.1016/j.csr.2009.06.009, 2009.

Baumann, T. M., Polyakov, I. V., Pnyushkov, A. V., Rember, R., Ivanov, V. V., Alkire, M. B., Goszczko, I., and Carmack, E. C.: On the Seasonal Cycles Observed at the Continental Slope of the Eastern Eurasian Basin of the Arctic, Ocean, J. Phys. Oceangr., 48, 1451-1470, https://doi.org/10.1175/JPO-D-17-0163.1, 2018.

Beszczynska-Möller, A., Fahrbach, E., Schauer, U., and Hansen, E.: Variability in Atlantic water temperature and transport at the entrance to the Arctic Ocean, 1997-2010, ICES J. Mar. Sci., 69, 852-863, 2012. 
Carmack, E., Polyakov, I., Padman, L., Fer, I., Hunke, E., Hutchings, J., Jackson, J., Kelley, D., Kwok, R., Layton, C., Melling, H., Perovich, D., Persson, O., Ruddick, B., Timmermans, M.L., Toole, J., Ross, T., Vavrus, S., and Winsor, P.: Toward quantifying the increasing role of oceanic heat in sea ice loss in the new Arctic, B. Am. Meteorol. Soc., 96, 2079-2105, https://doi.org/10.1175/BAMS-D-13-00177.1, 2015.

Carmack, E. C., Yamamoto-Kawai, M., Haine, T. W. N., Bacon, S., Bluhm, B. A., Lique, C., Melling, H., Polyakov, I. V., Straneo, F., Timmermans, M.-L., and Williams, W. J.: Freshwater and its role in the Arctic Marine System: Sources, disposition, storage, export, and physical and biogeochemical consequences in the Arctic and global oceans, J. Geophys. Res.-Biogeo., 121, 675-717, https://doi.org/10.1002/2015JG003140, 2016.

Dmitrenko, I. A., Polyakov, I. V., Kirillov, S. A., Timokhov, L. A., Simmons, H. L., Ivanov, V. V., and Walsh, D.: Seasonal variability of Atlantic water on the continental slope of the Laptev Sea during 2002-2004, Earth Planet. Sc. Lett., 244, 735-743, https://doi.org/10.1016/j.eps1.2006.01.067, 2006.

Fahrbach, E., Meincke, J., Osterhus, S., Rohardt, G., Schauer, U., Tverberg, V., and Verduin, J.: Direct measurements of volume transport through Fram Strait, Polar Res., 20, 217-224, 2001.

Grinsted, A., Moore, J. C., and Jevrejeva, S.: Application of the cross wavelet transform and wavelet coherence to geophysical time series, Nonlin. Processes Geophys., 11, 561-566, https://doi.org/10.5194/npg-11-561-2004, 2004.

Hattermann, T., Isachsen, P. E., von Appen, W.-J., Albretsen, J., and Sundfjord, A.: Eddy-driven recirculation of Atlantic Water in Fram Strait, Geophys. Res. Lett., 43, 3406-3414, https://doi.org/10.1002/2016GL068323, 2016.

Ivanov, V., Alexeev, V. A., Koldunov, N. V., Repina, I., Sandø, A. B., Smedsrud, L. H., and Smirnov, A.: Arctic Ocean heat impact on regional ice decay - a suggested positive, Feedback, J. Phys. Oceanogr., 46, 1437-1456, https://doi.org/10.1175/JPOD-15-0144.1, 2016.

Johns, W. E., Baringer, M. O., Beal, L. M., Cunningham, S. A., Kanzow, T., Bryden, H. L., Hirschi, J. J., Marotzke, J., Meinen, C. S., Shaw, B., and Curry, R.: Continuous, Array-Based Estimates of Atlantic Ocean Heat Transport at $26.5^{\circ} \mathrm{N}$, J. Climate, 24, 2429-2449, https://doi.org/10.1175/2010JCLI3997.1, 2011.

Karcher, M., Kauker, F., Gerdes, R., Hunke, E., and Zhang, J.: On the dynamics of Atlantic Water circulation in the Arctic Ocean, J. Geophys. Res., 112, C04S02, https://doi.org/10.1029/2006JC003630, 2007.

Kirillov, S. A., Dmitrenko, I. A., Ivanov, V. V., Aksenov, E. O., Makhotin, M. S., and de Quevas B. A.: The influence of atmospheric circulation on the dynamics of the intermediate water layer in the eastern part of the St. Anna Trough, Dokl. Earth Sci., 444, 630-633, 2012.

Koenig, Z., Provost, C., Sennéchael, N., Garric, G., and Gascard, J.-C.: The Yermak Pass Branch: A major pathway for the Atlantic Water north of Svalbard?, J. Geophys. Res., 122, 93329349, https://doi.org/10.1002/2017JC013271, 2017.

Li, F., Lozier, M. S., and Johns, W. E.: Calculating the Meridional Volume, Heat, and Freshwater Transports from an Observing System in the Subpolar North Atlantic: Observing System Simulation Experiment, J. Atmos. Ocean. Tech., 34, 1483-1500, https://doi.org/10.1175/JTECH-D-16-0247.1, 2017.
Lien, V. S. and Trofimov, A. G.: Formation of Barents Sea Branch Water in the north-eastern Barents Sea, Polar Res., 32, 18905, https://doi.org/10.3402/polar.v32i0.18905, 2013.

Loeng, H., Ozhigin, V., and Ådlandsvik, B.: Water fluxes through the Barents Sea, ICES J. Mar. Sci., 54, 310-317, 1997.

Morison, J., Kwok, R., Peralta-Ferriz, C., Alkire, M., Rigor, I., Andersen, R., and Steele, M.: Changing Arctic Ocean freshwater pathways, Nature, 481, 66-70, https://doi.org/10.1038/nature10705, 2012.

Nguyen, A.T., Ocaña, V., Garg, V., Heimbach, P., Toole, J. M., Krishfield, R. A., Lee, C. M., and Rainville, L.: On the benefit of current and future ALPS data for improving Arctic coupled ocean-sea ice state estimation, Oceanography, 30, 69-73, https://doi.org/10.5670/oceanog.2017.223, 2017.

Nøst, O. A. and Isachsen, P. E.: The large-scale time-mean ocean circulation in the Nordic Seas and Arctic Ocean estimated from simplified dynamics, J. Mar. Res., 61, 175-210, 2003.

Nurser, A. J. G. and Bacon, S.: The Rossby radius in the Arctic Ocean, Ocean Sci., 10, 967-975, https://doi.org/10.5194/os-10967-2014, 2014.

Onarheim, I. H., Smedsrud, L. H.. Ingvaldsen, R. B., and Nilsen, F.: Loss of sea ice during winter north of Svalbard, Tellus A, 66, 23933, https://doi.org/10.3402/tellusa.v66.23933, 2014.

Pedlosky, J.: Geophysical Fluid Dynamics, Springer-Verlag, New York, 710 pp., 1990.

Pérez-Hernández, M. D., Pickart, R. S., Pavlov, V., Våge, K., Ingvaldsen, R., Sundfjord, A., Renner, A. H., Torres, D. J., and Erofeeva, S. Y.: The Atlantic Water boundary current north of Svalbard in late summer, J. Geophys. Res., 122, 2269-2290, https://doi.org/10.1002/2016JC012486, 2017.

Pfirman, S. L., Bauch, D., and Gammelsrød, T.: The northern Barents Sea: water mass distribution and modification, in: The Polar Oceans and Their Role in Shaping the Global Environment, Geophysical Monograph 85, edited by: Johannessen, O. M., Muench, R. D., and Overland, J. E., American Geophysical Union, Hoboken, NJ, 77-94, 1994.

Pnyushkov, A. V. and Polyakov, I. V.: Observations of tidally-induced currents over the continental slope of the Laptev Sea, Arctic Ocean, J. Phys. Oceanogr., 42, 78-94, https://doi.org/10.1175/JPO-D-11-064.1, 2012.

Pnyushkov, A. V., Polyakov, I., Ivanov, V., and Kikuchi, T.: Structure of the Fram Strait branch of the boundary current in the Eurasian Basin of the Arctic Ocean, Polar Sci., 7, 53-71, https://doi.org/10.1016/j.polar.2013.02.001, 2013.

Pnyushkov, A. V., Polyakov, I., Ivanov, V., Aksenov, Y., Coward, A., Janout, M., and Rabe, B.: Structure and variability of the boundary current in the Eurasian Basin of the Arctic Ocean, Deep-Sea Res. Pt. I, 101, 80-97, https://doi.org/10.1016/j.dsr.2015.03.001, 2015.

Pnyushkov, A. V., Polyakov, I. V., Padman, L., and Nguyen, A. T.: Structure and dynamics of mesoscale eddies over the Laptev Sea continental slope in the Arctic Ocean, Ocean Sci. Discuss., https://doi.org/10.5194/os-2018-22, in review, 2018.

Polyakov, I. V.: CTD and Mooring Data from the Eastern Eurasian and Makarov Basins, and Northern Laptev and East Siberian Seas from 2013-2015, Arctic Data Center, arctic-data.7792.4, available at: https://arcticdata.io/catalog/\#view/arctic-data. 7792. 4/ (last access: March 2018), 2016. 
Polyakov, I. V., Timokhov, L. A., Dmitrenko, I., Ivanov, V. V., Simmons, H., Beszczynska-Möller, A., Dickson, R., Fahrbach, E., Fortier, L., Gascard, J.-C., Hölemann, J., Holliday, N. P., Hansen, E., Mauritzen, C., Piechura, J., Pickart, R., Schauer, U., Walczowski, W., and Steele, M.: Observational program tracks Arctic Ocean transition to a warmer state, Eos Trans. Am. Geophys. Union, 88, 398-399, 2007.

Polyakov, I. V., Alexeev, V. A., Belchansky, G. I., Dmitrenko, I. A., Ivanov, V. V., Kirillov, S. A., Korablev, A. A., Steele, M., Timokhov, L. A., and Yashayaev, I.: Arctic Ocean freshwater changes over the past 100 years and their causes, J. Climate, 21, 364-384, 2008.

Polyakov, I. V., Pnyushkov, A. V., and Timokhov, L. A.: Warming of the intermediate Atlantic Water of the Arctic Ocean in the 2000s, J. Climate, 25, 8362-8370, https://doi.org/10.1175/JCLI-D-1200266.1, 2012.

Polyakov, I. V., Bhatt, U. S., Walsh, J. E., Abrahamsen, E. P., and Pnyushkov, A. V.: Recent oceanic changes in the Arctic in the context of longer term observation, Ecol. Appl., 23, 1745-1764, https://doi.org/10.1890/11-0902.1, 2013.

Polyakov, I. V., Pnyushkov, A., Alkire, M., Ashik, I., Baumann, T., Carmack, E., Goszczko, I., Guthrie, J., Ivanov, V., Kanzow, T., Krishfield, R., Kwok, R., Sundfjord, A., Morison, J., Rember, R., and Yulin, A.: Greater role for Atlantic inflows on sea-ice loss in the Eurasian Basin of the Arctic Ocean, Science, 356, 285-291, https://doi.org/10.1126/science.aai8204, 2017.

Randelhoff, A., Sundfjord, A., and Reigstad, M.: Seasonal variability and fluxes of nitrate in the surface waters over the Arctic shelf slope, Geophys. Res. Lett., 42, 3442-3449, https://doi.org/10.1002/2015GL063655, 2015.

Renner, A. H. H., Sundfjord, A., Janout, M. A., Ingvaldsen, R., Beszczynska-Möller, A., Pickart, R., and Pérez-Hernández, M.: Variability and redistribution of heat in the Atlantic Water boundary current north of Svalbard, J. Geophys. Res., 123, 6373-6391, https://doi.org/10.1029/2018JC013814, 2018.

Rudels, B., Jones, E. P., Anderson, L. G., and Kattner, G.: On the intermediate depth waters of the Arctic Ocean, in: The Polar Oceans and their Role in Shaping the Global Environment, edited by: Johannessen, O. M., Muench, R. D., and Overland, J. E., Geophys. Monogr., 85, 33-46, 1994.

Rudels, B., Anderson, L. G., and Jones, E. P.: Formation and evolution of the surface mixed layer and halocline of the Arctic Ocean, J. Geophys. Res., 101, 8807-8821, 1996.

Schauer, U. and Beszczynska-Möller, A.: Problems with estimation and interpretation of oceanic heat transport: Conceptual remarks for the case of Fram Strait in the Arctic Ocean, Ocean Sci., 5, 487-494, https://doi.org/10.5194/os-5-487-2009, 2009.

Schauer, U., Muench, R. D., Rudels, B., and Timokhov, L.: Impact of eastern arctic shelf waters on the Nansen Basin intermediate layers, J. Geophys. Res., 102, 3371-3382, 1997.

Schauer, U., Rudels, B., Jones, E. P., Anderson, L. G., Muench, R. D., Björk, G., Swift, J. H., Ivanov, V., and Larsson, A.-M.: Confluence and redistribution of Atlantic water in the Nansen, Amundsen and Makarov basins, Ann. Geophys., 20, 257-273, https://doi.org/10.5194/angeo-20-257-2002, 2002.
Schauer U., Fahrbach, E., Osterhus, S., and Rohardt, G.: Arctic warming through the Fram Strait: Oceanic heat transport from 3 years of measurements, J. Geophys. Res., 109, C06026, https://doi.org/10.1029/2003JC001823, 2004.

Schauer, U., Beszczynska-Möller, A., Walczowski, W., Fahrbach, E., Piechura, J., and Hansen, E.: Variation of flow through the Fram Strait to the Arctic Ocean between 1997 and 2006, in: Arctic-Subarctic Ocean Fluxes, edited by: Dickson, B., Meincke, J., and Rhines, P., Springer, Dordrecht, 65-85, 2008.

Simmons, A., Uppala, S., Dee, D., and Kobayashi, S.: ERA-Interim: New ECMWF reanalysis products from 1989 onwards, ECMWF Newsletter, 110, 26-35, 2006.

Steele, M., Morley, R., and Ermold, W.: PHC: A global ocean hydrography with a high quality Arctic Ocean, J. Climate, 14, 2079-2087, 2001.

Thurnherr, A. M., Goszczko, I., and Bahr, F.: Improving LADCP Velocity with External Heading, Pitch, and Roll, J. Atmos. Ocean. Tech., 34, 1713-1721, https://doi.org/10.1175/JTECHD-16-0258.1, 2017.

Timmermans, M. L., Rainville, L., Thomas, L., and Proshutinsky, A.: Moored observations of bottom-intensified motions in the deep Canada Basin, Arctic Ocean, J. Mar. Res., 68, 625-641, https://doi.org/10.1357/002224010794657137, 2010.

Tsubouchi, T., Bacon, S., Naveira Garabato, A. C., Aksenov, Y., Laxon, S. W., Fahrbach, E., Beszczynska-Möller, A., Hansen, E., Lee, C. M., and Ingvaldsen, R. B.: The Arctic Ocean in summer: A quasi-synoptic inverse estimate of boundary fluxes and water mass transformation, J. Geophys. Res., 117, C01024, https://doi.org/10.1029/2011JC007174, 2012

Våge, K., Pickart, R. S., Pavlov, V., Lin, P., Torres, D. J., Ingvaldsen, R., Sundfjord, A., and Proshutinsky, A.: The Atlantic Water boundary current in the Nansen Basin: Transport and mechanisms of lateral exchange, J. Geophys. Res.-Oceans, 121, 69466960, https://doi.org/10.1002/2016JC011715, 2016.

Voinov, G. and Zakharchuk, E. A.: Large-scale variations of sea level in the Laptev Sea, in: Land-Ocean Systems in the Siberian Arctic: Dynamics and History, edited by: Kassens, H., Bauch, H. A., Dmitrenko, I., Eicken, H., and Hubberten, H.-W., SpringerVerlag, Berlin, 711 pp., 1999.

Woodgate, R. A., Aagaard, K., Muench, R. D., Gunn, J., Björk, G., Rudels, B., Roach, A. T., and Schauer, U.: The Arctic Ocean boundary current along the Eurasian slope and the adjacent Lomonosov Ridge: Water mass properties, transports and transformations from moored instruments, Deep-Sea Res., 48, 17571792, 2001.

Woodgate, R. A., Aagaard, K., and Weingartner, T. J.: Interannual changes in the Bering Strait fluxes of volume, heat and freshwater between 1991 and 2004, Geophys. Res. Lett., 33, L15609, https://doi.org/10.1029/2006GL026931, 2006.

Woodgate, R. A., Weingartner, T., and Lindsay, R.: The 2007 Bering Strait oceanic heat flux and anomalous Arctic sea-ice retreat, Geophys. Res. Lett., 37, L01602, https://doi.org/10.1029/2009GL041621, 2010.

Zakharchuk, E.: Anemobaric low-frequency waves in the Chukchi Sea, Russ. Meteorol. Hydrol., 34, 56-67, 2009. 